\title{
Global Monetarism and the Monetary Approach to the Balance of Payments
}

A DECADE OR So ago, when the twin concerns about the balance of payments of the United States and the functioning of the international monetary system began to impinge on the consciousness of a public theretofore indifferent to such esoterica, the opinions of those who were already paying attention fell into a neat dichotomy. Government officials and "men of affairs," on the one hand, insisted that the continued health of international trade, investment, and the world economy required the maintenance of the Bretton Woods system of pegged exchange rates, under which changes in rates were made infrequently and as a last resort. Academic experts, on the other hand, were nearly unanimous in pressing the advantages of greater flexibility of exchange rates, with many urging that governments abstain altogether from intervention and allow exchange rates to be determined by the interplay of supply and demand in the market-

This paper was supported partially by financial assistance from the Departments of State, Treasury, and Labor under Contract No. 1722-520176. However, the views contained herein are solely the author's and do not necessarily represent the official position of the U.S. government.

I am grateful to Edmond Alphandery, Rudiger Dornbusch, Jacob A. Frenkel, Peter B. Kenen, Norman C. Miller, and to the discussants and members of the Brookings panel for their helpful suggestions. 
place, just like any other price. ${ }^{1}$ The specter of competitive depreciation left over from the 1930s was replaced by concern about the rigidity of mechanisms for payments adjustment under the Bretton Woods system. Furthermore, the postwar wave of "elasticity pessimism" had given way to "elasticity optimism" as new empirical studies, better specified and using more sophisticated statistical techniques than their predecessors, indicated that demand elasticities were indeed high enough to ensure exchange-market stability and thus the effectiveness of exchange-rate changes as an instrument of balance-of-payments adjustment.

A number of assumptions, explicit or implicit, underlay the economic analysis of payments adjustment in the fifties and sixties and the resulting implications for balance-of-payments policies. To begin with, although the problem was ostensibly to restore equilibrium, or reduce disequilibrium, in the balance of payments, Keynesian analysis, with its emphasis on the components of aggregate demand, focused on the balance of trade (net exports of goods and services), which is one of those components. Net exports were assumed to be a function of aggregate demand and of relative prices at home and abroad; in the face of downward rigidity of wages and prices in the domestic market, changes in the exchange rate were the most effective means of altering those relative prices-hence the stress on the elasticities of home demand for imports and of foreign demand for exports. Although some analysts explored the effect on the capital account of changes in the relative profitability of investing at home and abroad, the main body of analysis assumed that, whatever effects particular policies might have on the other accounts in the balance of payments, the impact on the goods and services account would be dominant. ${ }^{2}$

One implication of this approach is that, in a world of fixed exchange rates and Keynesian downward rigidity in wages and prices, the price-

1. For two of the best-known academic briefs for flexible rates, see Milton Friedman, "The Case for Flexible Exchange Rates," in Richard E. Caves and Harry G. Johnson, eds., Readings in International Economics (Irwin, 1968), pp. 413-37, and Egon Sohmen, Flexible Exchange Rates, rev. ed. (University of Chicago Press, 1969). These essays were first published in 1953 and 1961, respectively.

2. This is true in particular of the classic work by J. E. Meade, The Theory of International Economic Policy, vol. 1: The Balance of Payments (London: Oxford University Press, 1951). Surveying the literature in the late 1960 s, Krueger noted that "there is no widely accepted theory incorporating both current and capital account items. The most thoroughly explored models in payments theory are those which consider only current account transactions and a means of payment." Anne O. Krueger, "Balance-of-Payments Theory," Journal of Economic Literature, vol. 7 (March 1969), p. 2. 
adjustment mechanism will not operate, at least in the deficit country, to restore payments equilibrium automatically and painlessly after a disturbance; rather, the restoration or maintenance of such external equilibrium must be an explicit target of economic policy. In the absence of exchangerate flexibility to alter relative prices, the most obvious mechanism for eliminating external imbalance is the Keynesian one: if exports are a function of foreign income (taken to be exogenously determined) and imports a function of domestic income, then a reduction of domestic income will lead to an improvement in the trade balance and thus in the balance of payments. Such a resolution of external payments problems is, however, likely to be unacceptable to governments committed to full employment as the primary domestic economic objective. ${ }^{3}$ And so a vast literature, incorporating capital mobility, quickly arose, directed toward developing a combination of policy instruments that would enable governments to achieve simultaneously the targets of internal balance (full employment) and external balance (payments equilibrium). ${ }^{4}$ But the proliferation of models of internal-external balance reinforced rather than weakened the conviction that governments would have greater success in achieving their domestic economic targets if they were able either to use exchange-rate changes as an additional policy tool (managed flexibility) or to exercise other policy instruments free of the balance-of-payments constraint imposed by pegged exchange rates (freely flexible rates). Furthermore, some argued, while, under fixed rates, changes in foreign income and expenditure would affect aggregate domestic income by altering the level of exports and thus the trade balance, freely flexible rates would insulate the domestic economy from foreign demand shifts and ensure that such disturbances would be bottled up where they originated, rather than spreading from one country to another via the Keynesian transmission belt.

3. Furthermore, if the domestic economy is stable in isolation (that is, the marginal propensity to save exceeds zero), the Keynesian income-adjustment mechanism will fall short of an automatic full restoration of external equilibrium in the wake of a balanceof-payments disturbance, as long as the feedback effects of the resulting disequilibrium in the money market are either disregarded or assumed to be neutralized by policy actions.

4. See Marina v. N. Whitman, Policies for Internal and External Balance, Special Papers in International Economics 9 (Princeton University, International Finance Section, 1970) for a survey of that literature. One practical application in the United States was "Operation Twist" of the early 1960s, which sought to attract capital inflows with high short-term interest rates while keeping long-term rates low to stimulate domestic expansion. 
Today, most major industrialized countries are no longer bound to pegged exchange rates. But a funny thing happened on the way to this flexible-rate nirvana. The post-Bretton Woods world of managed flexibility has produced surprises undreamed of in the analyses of the 1950s and 1960s; moreover, a small but influential group of international economists has stood traditional balance-of-payments analysis on its head. I have termed this group the "global monetarists"--"monetarists" because of their belief that macroeconomic phenomena can be analyzed best in terms of the relationship between the demand for and the supply of money, and "global" because of their conviction that, as a first approximation, the world consists, not of separable national economies, but of a single, integrated, closed economy.

From these two fundamental tenets arise a number of startling propositions. Put in their most extreme form, they include the following: A change in the exchange rate will not systematically alter the relative prices of domestic and foreign goods and it will have only a transitory effect on the balance of payments. Any exercise of monetary policy to change the domestic component of the monetary base will, under fixed exchange rates, be offset by an equal and opposite change in the foreign component of that base. Thus, exchange-rate policy cannot permanently alter the balance of payments and monetary policy cannot lastingly affect the domestic economy, but a change in the exchange rate will have a direct impact on the domestic price level, and monetary policy will have a direct effect on the country's payments position (measured by the change in its reserves under a fixed-rate system, by the movement in its exchange rate under freely flexible rates, and by a combination of the two under managed flexibility). Not only are exchange-rate changes ineffective as an instrument of balanceof-payments policy for the long run, they are also unnecessary; indeed, there is no need to make external balance an explicit target of national economic policy, since an automatic adjustment mechanism can be counted on to restore such balance in the wake of an exogenous disturbance that moves a nation's balance of payments temporarily away from equilibrium. Finally, flexible exchange rates are not merely superfluous but positively detrimental to world economic welfare, because they eliminate the international pooling of risks and the efficiency advantages of international money associated with fixed exchange rates. ${ }^{5}$

5. For a popular exposition of these views, see Jude Wanniski, "The Mundell-Laffer Hypothesis-A New View of the World Economy," Public Interest, no. 39 (Spring 1975), 
Far from being new, these propositions of the global monetarists represent a return to a tradition far older than the Keynesian approach they are challenging - to the price-specie-flow mechanism of David Hume, who argued that the international flows of reserves engendered by a payments imbalance would, through their effects on national money supplies and price levels and thus on the trade balance, automatically restore external balance. ${ }^{6}$ Nonetheless, these views pose a direct challenge to the current orthodoxy, and they have revolutionary implications for balance-of-payments policy and even for balance-of-payments accounting.

\section{The Skeleton Model: A Tripartite Structure}

To assess these implications, and evaluate the relative merits of the Keynesian and the global-monetarist prescriptions for contemporary U.S. policy, requires first describing the analytical underpinnings of this new-old approach and ascertaining where it can, and cannot, be reconciled with current orthodoxy. ${ }^{7}$ These tasks, in turn, call for an examination of the various, frequently intertwined, intellectual strands that together give the

pp. 31-52. The economists referred to in the title are Robert Mundell and Arthur Laffer, two leading proponents of global monetarism. The modern incarnation of global monetarism was developed during the late 1950s and 1960s, primarily in a series of articles by Mundell, many of which are collected or further developed in two books by him: International Economics (Macmillan, 1968) and Monetary Theory: Inflation, Interest, and Growth in the World Economy (Goodyear, 1971). Mundell's work in turn grew out of some earlier work by Polak: J. J. Polak, "Monetary Analysis of Income Formation and Payments Problems," International Monetary Fund Staff Papers, vol. 6 (November 1957), pp. 1-50, and J. J. Polak and Lorette Boissonneault, "Monetary Analysis of Income and Imports and Its Statistical Application," ibid., vol. 7 (April 1960), pp. 349-415.

6. See Jacob A. Frenkel, "Adjustment Mechanisms and the Monetary Approach to the Balance of Payments: A Doctrinal Perspective," in E. Classen and P. Salin, eds., Recent Issues in International Monetary Economics (Amsterdam: North-Holland, forthcoming, 1976).

7. To make clear what is meant by "current orthodoxy," I quote from Johnson: "The quantity-theory counter-revolution . . . has been directed against the so-called 'income-expenditure' school, by which is meant those economists in the Keynesian tradition who have concentrated their analysis and policy prescriptions on the incomeexpenditure side of the Keynesian general-equilibrium apparatus. (This focus has been the dominant impact of the Keynesian revolution on governmental and other practical thinking on economic forecasting and policy-making)." Harry G. Johnson, Further Essays in Monetary Economics (Harvard University Press, 1973), pp. 28-29. 
approach its distinctiveness. In order to anchor the discussion in a specific example, I have borrowed, with minor modifications, a stripped-down, one-commodity, two-country model which, while it cannot do justice to the richness and complexity either of the relevant literature in general or of its originator's work in particular, serves as a convenient aid to exposition: ${ }^{8}$

$$
\begin{gathered}
L=k P \bar{y} \\
L^{*}=k^{*} P^{*} \bar{y}^{*} \\
P=P^{*} e \\
M=\bar{D}+R \\
M^{*}=\bar{D}^{*}+R^{*} \\
\dot{M}=\dot{R}=H=B=-e H^{*}=-e \dot{R}^{*}=-e \dot{M}^{*} \\
Z=P \bar{y}-H \\
Z^{*}=P^{*} \bar{y}^{*}-H^{*} \\
H=\Pi(L-M)=H(P, M) \\
H^{*}=\Pi\left(L^{*}-M^{*}\right)=H^{*}\left(P^{*}, M^{*}\right),
\end{gathered}
$$

where an asterisk indicates variables for the foreign country and a dot indicates rate of change, and

$L=$ desired nominal money balances

$k=$ desired ratio of nominal money balances to nominal income

$\bar{y}=$ real output (taken as exogenous)

$P=$ money price of goods in terms of domestic currency

$e=$ exchange rate (domestic currency price of foreign exchange)

$M=$ nominal quantity of money

$\bar{D}=$ domestic component of the domestic money supply (taken as exogenous)

$R=$ international component of the domestic money supply

$B=$ trade-balance surplus, measured in domestic currency

$Z=$ desired nominal expenditure

$H=$ flow demand for money (hoarding function)

$\Pi=$ rate of adjustment of actual to desired money balances.

These equations define a simple macroeconomic general-equilibrium model, in contrast to both the conventional price-adjustment (elasticities)

8. Rudiger Dornbusch, "Devaluation, Money, and Nontraded Goods," American Economic Review, vol. 63 (December 1973), pp. 871-80. 
approach, which is clearly microeconomic and partial-equilibrium, and the income-adjustment approach which, although based on the Keynesian macroeconomic model, is not truly a general-equilibrium view in that it ignores the interactions between the goods market and the money market. ${ }^{9}$ The global monetarists stress the importance of these interactions; more generally, they insist that, when one market is eliminated from a generalequilibrium model by Walras' law, the behavioral specifications for the included markets must not be such as to imply a specification for the excluded market that would appear unreasonable if it were made explicit. ${ }^{10}$

This model is also characteristic of the genre in that it specifies both the equilibrium characteristics of the long-run steady state, in equations 1 and 2 , and the dynamic adjustment process by which the steady state is approached, in equations 4-6. In contrast with the "medium run" of conventional Keynesian analysis, which defines equilibrium in flow terms alone, in this approach full equilibrium involves the achievement of stock as well as flow equilibrium in all markets. Having thus resolved one of the inconsistencies of Keynesian analysis, however, this view retains and even intensifies another, in that it combines long-run full-equilibrium assumptions on the demand side with the essentially short-run assumptions of the stationary state on the output side. ${ }^{11}$

9. For an explanation of why these traditional modes of analysis are fundamentally Keynesian, see the section below on reconciliation of the various approaches.

10. See Lance Girton and Don Roper, "A Monetary Model of Fixed and Flexible Exchange Rates Applied to the Postwar Canadian Experience," American Economic Review (forthcoming, 1976), and Harry G. Johnson, "The Monetary Theory of Balanceof-Payments Policies," in Jacob A. Frenkel and Harry G. Johnson, eds., The Monetary Approach to the Balance of Payments (London: Allen and Unwin; Toronto: University of Toronto Press, 1976).

11. The equilibrium conditions for the stationary state can be converted into growth terms by recognizing that, under conditions of growth, money-market equilibrium requires, not a zero balance of payments, but rather a balance determined by the following conditions: (a) the rate of inflation must be the same in both countries, and (b) in each country the growth of the real money stock must be equal to the increase in demand for real money balances occasioned by growth. For the equilibrium balance of payments these conditions together imply

$$
B=\frac{M}{P}\left(g_{P}+g_{y}-g_{D}\right)=\frac{M^{*}}{P^{*}}\left(g_{D}^{*}-g_{P}-g_{y}^{*}\right),
$$

where $g_{i}=(d i / d t) / i$ for all variables. See Mundell, Monetary Theory, chap. 15, and for a similar formulation, Harry G. Johnson, "The Monetary Approach to Balance-of-Payments Theory," in Frenkel and Johnson, eds., Monetary Approach. All the long-run conclusions of the monetary approach derived from the stationary-state model can thus be translated into equilibrium growth terms without altering the qualitative results, except that in the latter case it is possible to obtain persistent flow-equilibrium deficits or surpluses on the basis of stock adjustments in the money market. 
Finally, this two-country model describes a situation in which, under fixed exchange rates, the world is a closed, integrated economy, with a single money stock and price level, while each country is an open economy characterized by major leakages. Such an approach is internationalist, stressing the interactions among economies in an interdependent world and, by implication, the futility of attempting to analyze-or manage-a national economy in isolation. All this contrasts strongly with the traditional Keynesian focus on the national economy as the fundamental unit, in which "foreign repercussions" are second-order effects that can affect the magnitude but not the direction of the primary impact of disturbances or policies on a relatively "closed" economic unit.

In addition to reflecting some of the general characteristics of the globalmonetarist approach, these equations make it possible to identify three strands of key assumptions that together distinguish this approach from the conventional Keynesian one, but that can be evaluated independently of one another.

The first equation embodies the neutrality assumption that is the linchpin of monetarism, whether in the context of a closed or an open economy..$^{12}$ In making the level of real income exogenous to the system, equation 1 assumes a classical world in which real output is constant (at the full-employment level) ${ }^{13}$ and all prices, including wages, are fully flexible. The one-toone relationship between the supply of money and the aggregate price level implies an absence of money illusion and the long-run neutrality of money vis-à-vis real variables. The Cambridge form of equation 1 also assumes an interest-inelastic or "super-stable" demand-for-money function. This particular formulation embodies an additional implication: the impotence of fiscal policy to affect any aspect of the economy, including the price level.

The open-economy view that is the second leg of the global-monetarist stool is reflected in equation 2 . This is the assumption of perfect commodity arbitrage, which ensures that, in the absence of barriers to trade, the "law of one price" must hold in integrated world commodity markets. ${ }^{14} \mathrm{Al}$ though the assumption of this law at the microeconomic level of a single

12. For the argument that this proposition is the critical one in distinguishing monetarists from nonmonetarists, see Don Roper, "Two Ingredients of Monetarism in an International Setting," Seminar Paper 46 (Stockholm: Institute for International Economic Studies, April 1975; processed).

13. Or, alternatively, at the level of Friedman's natural rate of unemployment.

14. The counterpart of the "law of one price" in single-country models is the "small country" assumption, under which the domestic price level (and also the domestic rate of interest, in models that incorporate a bond market) is assumed to be exogenously determined, under fixed exchange rates, by the price level in the outside world. 
good is widely accepted, its elevation to a macroeconomic level distinguishes global monetarism from alternative approaches. In other words, an implicit assumption either of perfect substitutability, or of fixed relative commodity prices, enables the analysis to apply to a single-commodity world (which immediately translates the law into a "law of one price level," as here) or to a two-commodity world (where the distinction is between traded and nontraded goods). Such aggregation abstracts, in particular, from changes in the relative prices of exports and imports-that is, in a country's terms of trade. The terms of trade are a significant element of the elasticities approach because the implicit assumption it embodies-that the domestic-currency price of home goods is held constant either by perfectly elastic supply or by the government's stabilization policies-makes it possible to equate changes in the exchange rate with changes in the barter terms of trade, or at least to postulate a systematic relationship between the two. The global-monetarist approach, in contrast, makes an alternative assumption-that the nominal quantity of money is held constant under devaluation in the short run-which implies no such relationship. The absence of such a relationship justifies the level of commodity aggregation characteristic of global-monetarist models and their focus on exchange rates to represent the relative prices of national moneys rather than of national goods.

The third leg of global monetarism, the automatic monetary mechanism for payments adjustment, often termed "the monetary approach" to the balance of payments, ${ }^{15}$ itself has two parts. The first is the assertion that, when the central bank pegs the exchange rate, the national money supply becomes an endogenous, rather than a policy, variable. This view is reflected in equation 3, which (ignoring the base-money multiplier for simplicity) divides the money supply into domestic-credit and internationalreserve components, and equation 4 , which spells out the feedback from the balance of payments (a surplus or deficit being definitionally equivalent to a change in the country's stock of reserves) onto the national money stock. ${ }^{16}$ It is in sharp contrast with the assumption, frequently implicit in

15. The incorporation of this view into the received wisdom of balance-of-payments theory is symbolized by the difference between the fourth edition of Charles P. Kindleberger's widely used text, International Economics (Irwin, 1968), which makes no mention of the monetary approach, and the fifth edition (Irwin, 1973), which devotes an entire chapter to it.

16. Note that equation 4 assumes implicitly that the capital gains (losses) on international reserves, measured in domestic currency, arising from devaluation (revaluation) are sterilized by the central bank. 
conventional Keynesian analysis, that the monetary authorities sterilize the impact on the domestic money supply of international reserve flows arising from payments imbalance (and that the effects of such sterilization operations on the stock of private wealth can be ignored).

Equations 5 and 6 together embody the second part of the automatic adjustment mechanism of the monetary approach-the assertion (a) that the relationship between the demand for and the supply of money plays a key role in the functioning of all markets in the economy; and (b) that the demand for money is fundamentally a stock demand characteristic of asset markets rather than a flow demand appropriate to output (commodity) markets. ${ }^{17}$ Specifically, equation 5 embodies a form of "real balance" effect that makes the desired level of expenditure a function of wealth as well as income. Here, this effect produces a flow demand for money which is represented in equation 6 as a function of the difference between the desired and actual stocks of money. Thus, although the underlying equilibrium in the money market is a stock equilibrium, it is not achieved instantaneously, and the flow demand for money (the hoarding function) arises from the gradual adjustment of actual money balances toward the desired stock. The existence of this partial-adjustment mechanism in the market for money balances drives a wedge between short-run and long-run equilibrium, and between the short-run impact and the long-run stationary-state effects of policy actions and other exogenous disturbances.

The very simplicity and rigidity of this particular model enable it to yield unambiguous analytical results and strong policy conclusions. Within its confines, the short-run effects of a one-shot change in the pegged exchange rate are clear: by raising the domestic price level (equation 2) and thus the demand for money balances (equation 1), a devaluation stimulates hoarding (equation 6) and brings about a clear-cut improvement in the

17. This stock definition of equilibrium in asset markets has at least three major antecedents in the modern literature of international finance. The first is the "realbalance effect" described in the seminal article on the absorption approach by Sidney $\mathbf{S}$. Alexander, "Effects of a Devaluation on a Trade Balance" (1952); the second is the distinction between stock and flow payments disequilibria made by Harry G. Johnson in his 1961 article, "Towards a General Theory of the Balance of Payments." Both of these papers are reprinted in Caves and Johnson, eds., Readings in International Economics. Finally, there are the open-economy portfolio-balance models, whose development began in the mid-1960s; for example, Ronald I. McKinnon and Wallace E. Oates, The Implications of International Economic Integration for Monetary, Fiscal, and Exchange-Rate Policy, Studies in International Finance 16 (Princeton University, Intersnational Finance Section, 1966). 


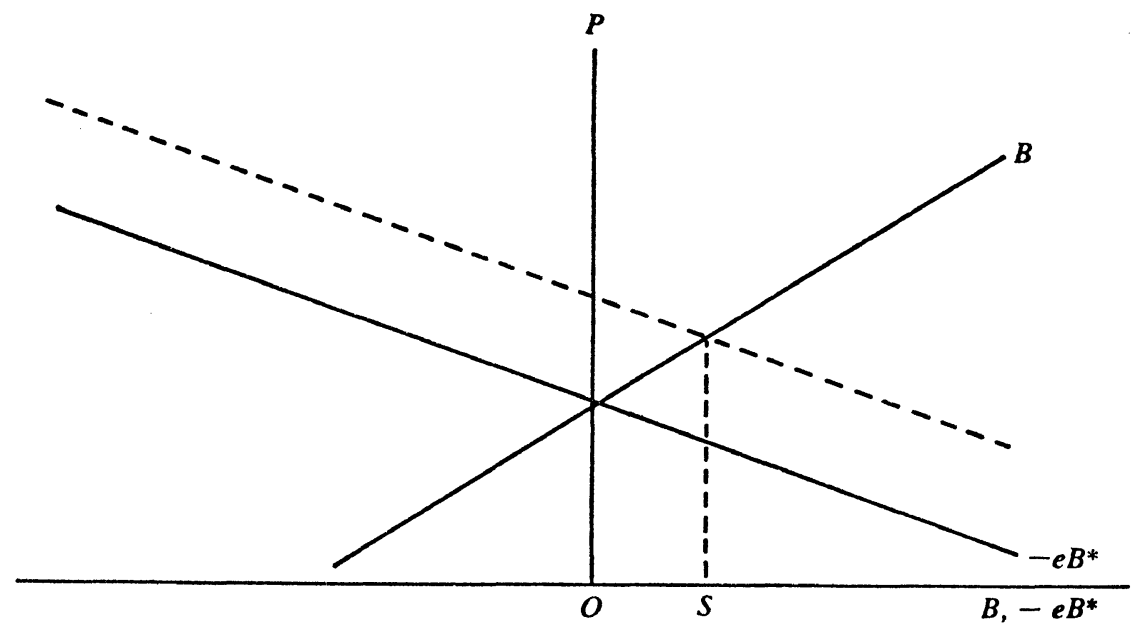

payments balance (without, it should be noted, any terms-of-trade or relative-price effects) and a redistribution of the world money supply toward the devaluing country (equation 4). This is clear in the substitution from equations 1 and 4 into equation 6 to derive the two equations for $B$ shown (for a situation of initial long-run equilibrium) in the accompanying diagram. For the home country, $\bar{M}+(B / \Pi)=k P \bar{y}$, or $B=\Pi(k P \bar{y}-\bar{M})$. Thus, $(d B / d P)>0$, giving the equation for $B$ its positive slope in the diagram. For the foreign country, similarly,

$$
B^{*}=\Pi^{*}\left(k^{*} \frac{P}{e} \bar{y}^{*}-\bar{M}^{*}\right) .
$$

But $B=-e B^{*}$, so $B=\Pi^{*}\left(-k^{*} P \bar{y}^{*}+e \bar{M}^{*}\right)$ and $(d B / d P)<0$, giving the equation for $-e B^{*}$ its negative slope in the diagram. Furthermore,

$$
\frac{d B}{d e}=\Pi k \bar{y}\left(\frac{\Pi^{*} M^{*}}{\Pi k \bar{y}+\Pi^{*} k^{*} \bar{y}^{*}}\right)>0,
$$

so that devaluation causes an upward shift in $-e B^{*}$, producing a payments (trade) surplus equal to $O S$ for the home country.

The effect on the balance of payments is only transitional, however; over time, as the world money stock is redistributed and $(L-M)$ approaches $0, S$ approaches 0 also, and $-e B^{*}$ moves gradually down toward its original position. In the long run, when full stock equilibrium is reached in the money market $(L=M)$, and hoarding is therefore equal to zero, the balance of payments is again zero as well. In the long run, furthermore, de- 
valuation has no effect on any real economic variables, but simply raises the aggregate price level in proportion to the increase in the domestic money stock, which is the integral of the payments surplus over the transitional period (when $B=0, P=(M / k \bar{y})$ and $(d P / d M)=1) \cdot{ }^{18}$ And, finally, because in the long run $R=L-D$, any change in the domestic component of the money supply (with the demand for money unchanged) is ultimately fully offset by an equal opposite change in the internationalreserve component through the balance of payments.

\section{Clothing the Skeleton: Some Extensions of the Model}

The model just described was deliberately cut to its bare bones in order to reveal the essential structure underlying global monetarism. Many analysts have, of course, built on this skeleton by eliminating or severely modifying one or more of the three strands of global-monetarist assumptions while leaving the others intact. Some, for example, replace the classical full-employment assumption embodied in equation 1 with the Keynesian assumption of wage-price stickiness and underemployment, thus making real output endogenously variable and eliminating the proportionality between the nominal money stock and the price level. In so doing, they replace or supplement the Humean price-specie-flow mechanism that drives the model of the previous section with what Mundell has termed a Keynesian income-specie-flow mechanism. ${ }^{19}$ This introduction of an elastic supply curve for output eliminates the neutrality assumption central to monetarism, but retains the automatic monetary mechanism of payments adjustment that makes payments imbalances transitory and inconsistent with stationary-state equilibrium.

A second class of extensions of this basic model involves broadening the spectrum of financial assets in the system to include bonds or other types of interest-bearing securities as well as money, thus reinserting the interest rate as an argument of certain behavioral relationships (for example, in equation 1 above) and reintroducing the portfolio-balance considerations

18. It can easily be shown that the division of a devaluation between a rise in the home country's price level and a fall in the foreign country's price level is inversely proportional to the sizes of the two countries' initial money stocks. See Dornbusch, "Devaluation, Money, and Nontraded Goods," p. 874.

19. Mundell, International Economics, p. 218. 
pioneered in the open-economy context by McKinnon and Oates. ${ }^{20}$ In such models, the money-market stock-equilibrium condition of equation 1 is transformed into an asset-equilibrium condition that incorporates all financial assets. ${ }^{21}$ Such models generally also introduce a "budget constraint" equation for the government sector, which acts as supplier of bonds to the private sector. This provision marks a contrast with the basic model utilized here which, although it may be used to analyze the impact of such policyinduced shocks as a devaluation or a one-shot change in the domestic component of the money supply, is essentially a model of the private sector. This extension of the model, furthermore, admits the existence of international capital flows and thus a distinction between the balance of trade and the balance of payments.

Relaxing the second strand of global monetarism, which I have termed the "law of one price level" and which is reflected in equation 2 above, means moving away from the high degree of aggregation employed in such a one-commodity model. Assuming the existence of nontraded goods, or of less-than-perfect substitutability between domestic and foreign goods (or assets), allows for the possibility of shifts in relative prices and restores some degree of independence to the domestic interest rate and price level..$^{22}$

These extensions and refinements naturally introduce considerable ambiguity into the analytical conclusions that can be derived and qualify in one way or another the strong policy implications of the pure global-monetarist model. In models allowing for shifts in relative prices between home and foreign or between traded and nontraded goods, for example, the short-run impact of a devaluation is no longer "neutral"; the alteration of relative

20. "Implications of International Economic Integration." Among more recent portfolio-balance models for an open economy are William $\mathrm{H}$. Branson, "Macroeconomic Equilibrium with Portfolio Balance in Open Economies," Seminar Paper 22 (Stockholm: Institute for International Economic Studies, November 1972; processed); Rudiger Dornbusch, "A Portfolio Balance Model of the Open Economy," Journal of Monetary Economics, vol. 1 (January 1975), pp. 3-20; Jacob A. Frenkel and Carlos A. Rodriguez, "Portfolio Equilibrium and the Balance of Payments: A Monetary Approach," American Economic Review, vol. 65 (September 1975), pp. 674-88.

21. The use of money balances rather than the total stock of financial assets as an argument of the expenditure function not only attributes special importance to money but also implicitly assumes a low (in the limit, zero) elasticity of substitution between money and other assets.

22. For example, Branson, "Macroeconomic Equilibrium with Portfolio Balance"; Rudiger Dornbusch, "Capital Mobility and Portfolio Balance," in Robert Z. Aliber, ed., The Political Economy of Monetary Reform (London: Macmillan, forthcoming); and the second part of Dornbusch's "Devaluation, Money, and Nontraded Goods." 
prices affects real variables over the period of transition to a new stock equilibrium. More generally, in these more complicated models, the initial effect of various exogenous disturbances and the characteristics of the dynamic adjustment path toward long-run stock equilibrium are extremely sensitive to assumptions about the way in which expectations are formed, ${ }^{23}$ which markets clear instantaneously and which approach equilibrium gradually, whether prices or quantities perform the clearing function, and the nature of the adjustment mechanism in markets that clear only with a lag. ${ }^{24}$

Despite the ambiguity produced by various modifications of the basic global-monetarist model, its long-run stationary-state implications necessarily remain robust to a wide variety of alternative specifications as long as the third strand of global monetarism, the monetary approach to the balance of payments, is retained. The essentials of the monetary approach, it will be recalled, are (1) the nonsterilization assumption, which links changes in the domestic money supply to disequilibria in the balance of payments as indicated in equations 3 and 4; and (2) the associated implication that the equilibrium values in the income-expenditure equation will be changing as long as the nominal quantity of money, $M$, is changing (as indicated by the dynamic adjustment process specified in equations 5 and 6 ), and that they cannot come to rest until the system is in full stock equilibrium.

The adjustment mechanism that characterizes the monetary approach to the balance of payments does not, however, require the incorporation of money directly into the expenditure function. In a model with interestbearing assets, disequilibrium in the money market will feed back onto other markets, even if money is not an argument of the expenditure function, by causing changes in the rate of interest, which is traditionally an argument of both the expenditure and the money-demand functions. To put it in the familiar terminology of macroeconomics textbooks, shifts in the supply of or demand for money can affect aggregate demand either

23. Gordon argues that the nature of expectations formation, as well as the degree of short-run price flexibility, determines whether domestic stabilization policies can be effective in the short run. Robert J. Gordon, "Recent Developments in the Theory of Inflation and Unemployment," Journal of Monetary Economics (forthcoming, April 1976).

24. For a detailed analysis of the differing implications of two specifications of the adjustment process in an otherwise identical model, see Polly Reynolds Allen and Peter B. Kenen, "Portfolio Adjustment in Open Economies: A Comparison of Alternative Specifications," Weltwirtschaftliches Archiv (forthcoming, March 1976). 
directly, by shifting the IS curve, or indirectly, by shifting the LM curve and thus the rate of interest. Therefore, unless the economy is assumed to be in a situation in which changes in the stock of money have no impact on income (either a Keynesian liquidity or marginal-efficiency trap), the automatic payments-adjustment mechanism, which is the linchpin of the monetary approach to the balance of payments, will still operate, whether the link between the money market and expenditures is direct or indirect. ${ }^{25}$

In sum, the kind of global-monetarist model that yields the policy implications outlined in the opening section of this paper involves much more than simply the monetary approach to the balance of payments. ${ }^{26}$ The latter is "monetary" in the sense that it postulates a direct relationship between the balance of payments and the money supply and requires that the equation for stock equilibrium in the money market be included in the solution set for a model of an open economy. The strict global-monetarist view goes much further, however, implying either that monetary disturbances to the economy generally dominate nonmonetary ones or that the impact of any exogenous shock, whatever its nature and origin, can best be analyzed via the relationship between the demand for and the supply of money.

\section{The Various Approaches: A Formal Reconciliation}

One way of exposing the analytical differences among the various approaches to balance-of-payments analysis is to make explicit the nature of the assumptions required to make them formally consistent with one another. Mundell outlines the framework for such a reconciliation by characterizing three approaches to balance-of-payments analysis (at first abstracting, for simplicity's sake, from capital movements, so that the balance of trade and the balance of payments are identical; all aggregates are in nominal terms):

25. See Mundell, International Economics, chap. 15, and Carlos A. Rodriguez, "Money and Wealth in an Open Economy Income-Expenditure Model," in Frenkel and Johnson, eds., Monetary Approach.

26. The two are often confused. In a strongly worded protest, Harry Johnson complains that "there has been a noticeable tendency to dismiss the new [monetary] approach as merely an international economics application of an eccentric and intellectually ludicrous point of view of a contemporary lunatic fringe referred to as 'monetarism.' "The Monetary Approach to Balance-of-Payments Theory: A Diagrammatic Analysis," Manchester School, vol. 43 (September 1975), p. 221. 
1. The elasticity approach takes the balance-of-payments equation, $B=$ $X-M$ (where $X$ and $M$ are exports and imports, respectively), directly, differentiates it totally with respect to the exchange rate, translates the results into elasticities form, and thus establishes the "elasticity conditions" showing the effects of a change in the exchange rate on the balance of trade, "assuming that export and import prices adjust to equate the demand and supply of exports and imports."

2. The absorption approach takes, from national-income accounting, the relationship $B=Y-E$ (where $Y$ is nominal income and $E$ is domestic expenditure or absorption) and points out that a policy change, such as a devaluation, can improve the balance of trade only if it increases income by more than expenditures.

3. The monetary approach stresses that the balance of payments implies a change in the foreign-reserve holdings of the central bank, and that this change must equal the difference between the total increase in the domestic money supply and domestic credit creation; that is, $B=H-C$ (where $H$ is hoarding or additional money stocks and $C$ is domestic credit creation). The introduction of capital movements makes no difference to the validity of this approach. ${ }^{27}$

Mundell points out that the terms in each of the three approaches "can be defined so that they are all correct and assert identical propositions, even if capital movements are included." Taking all variables as ex post identities, he notes that "from national income accounting we have $Y \equiv E+B$; from banking accounts we have $H \equiv C+R$ [R is the increase in reserves]; and from the balance-of-payments accounts we have $R \equiv B-T$, where $T$ represents net capital exports. It follows, then, that $R \equiv B-T \equiv Y-$ $E-T \equiv H-C .{ }^{\prime 28}$

A simple equality among ex post or accounting identities is not very meaningful, however, and one must look behind these identities to see just how the variables are defined, and what implicit assumptions underlie these definitions, in order to produce the reconciliation just outlined. Furthermore, the discussion is complicated because most of the comparisons here have been cast in terms of the monetary approach on the one hand and the conventional or Keynesian approach on the other, and there are several significantly different variants of the latter despite the fundamental Keynesian spirit common to all of them.

The elasticities approach to balance-of-payments analysis is clearly

27. International Economics, pp. $150-51$. The quote in point 1 is on p. 150 .

28. Ibid., p. 151. 
Keynesian in the sense that only under Keynesian assumptions of unemployment and wage-price rigidity in domestic markets can it be assumed that "a devaluation would change the real prices of domestic goods relative to foreign goods in the foreign and domestic markets, thereby promoting substitutions in production and consumption," and that "any repercussions of these substitutions on the demand for domestic output could be assumed to be met by variations in output and employment." ${ }^{29}$ However, these Keynesian assumptions alone are not sufficient to define the generalequilibrium implications of the partial-equilibrium elasticities approach. In particular, when the formal model underlying the elasticity conditions is spelled out, it generally makes the volume of exports and of imports (or, more precisely, foreign excess demand for export goods and domestic excess demand for import goods, respectively) each a function of its own money price, rather than of their relative prices and total real income (as in the barter model of pure trade theory) or of relative prices and the difference between actual and desired money stocks (as in a full general-equilibrium model). It turns out that the functional relationships implicit in the elasticities approach can be reconciled with those of general-equilibrium analysis, and thus with the monetary approach, under the following assumptions: (1) in each country there is a nontraded commodity; (2) this commodity dominates the budgets of consumers; (3) the objective of stabilization policy (monetary or fiscal) in each country is to keep the money price of the nontraded good fixed; and (4) all cross-price elasticities between traded goods are zero. ${ }^{30}$

The reconciliation of the monetary approach with the absorption approach is considerably less complicated, since "the monetary approach in its simplest form ... can be considered as a pure absorption approach, in which the demand for money relative to its initial supply determines absorption [relative to income]." ${ }^{31}$ Indeed, the father of the modern absorption approach himself noted that "the cash balance effect is perhaps the

29. "Monetary Approach to Balance-of-Payments Theory." Note, incidentally, that it is not strictly necessary for relative prices of domestic and foreign goods to change in order to induce substitutions in production if the relative costs of factors of production change. Such changes are also ruled out by the usual Keynesian assumptions.

30. Murray C. Kemp, The Pure Theory of International Trade (Prentice-Hall, 1964), pp. 235-36, and Rudiger Dornbusch, "Exchange Rates and Fiscal Policy in a Popular Model of International Trade," American Economic Review, vol. 65 (December 1975), pp. 859-71.

31. Patrick Minford, "Substitution Effects, Speculation, and Exchange Rate Stability" (University of Manchester, 1975; processed), p. 143. 
best known of the direct absorption effects." ${ }^{32}$ One difference between the two approaches is that the monetary view focuses on the real-balance effect exclusively. A second is that the absorption approach incorporates by implication markets for commodities and money only, so that the difference between aggregate income and aggregate expenditure equals the balance of trade. The monetary approach, on the other hand, sometimes introduces a market for bonds, allowing disequilibrium in the money market to be reflected not only in the commodities market (and thus the balance of trade), but also in the market for bonds (and thus the capital account); hence, such a disequilibrium is reflected in the overall balance of payments (the trade account plus the capital account). ${ }^{33}$

It remains to note that the absorption approach is a variant-or, more accurately, a generalization-of Keynesian multiplier analysis. Both stem from the basic national-income accounting identity, $Y=C+I+X-M$ (omitting the government sector, $G-T$, for the sake of simplicity), where $C$ is consumption and $I$ is investment. Setting $C+I=E$ (expenditure or absorption) yields $Y-E=X-M=B$, the starting point for the absorption approach. The usual (linearized) multiplier analysis is a special case of the absorption approach in that it assumes (1) that changes in imports are a constant proportion, $m$, of changes in income; (2) that all changes in aggregate demand are met by changes in output at constant prices (either because supply is infinitely elastic below full employment or as a result of deliberate government policy $\left.{ }^{34}\right)$; and (3) that changes in saving are also a constant fraction, $s$, of changes in income. Taken together, these assumptions ensure, first, that a policy action - such as devaluation-designed to increase $B$ will operate by increasing real output, $Y$; and, second, that multiplier effects on income will operate to reduce the impact effect of a devaluation on the balance of payments but will never, given a positive marginal propensity to save, eliminate or reverse it. ${ }^{35}$

32. Alexander, "Effects of a Devaluation," p. 367.

33. Salop shows, in an ex post accounting framework, how one approach can be derived from the other, using Walras' law, introducing the market for bonds, and utilizing the budget constraints faced by the various sectors in the economy. Joanne Salop, "A Note on the Monetary Approach to the Balance of Payments," in Peter B. Clark, Dennis Logue, and Richard J. Sweeney, eds., The Effects of Exchange Rate Adjustment (U.S. Department of the Treasury, forthcoming, 1976).

34. The latter assumption is made by Meade in Theory of International Economic Policy. Note that this approach also implies that the country is specialized in the production of its export good.

35. It is possible also to combine the elasticity and multiplier approaches, taking the elasticity effects as impact effects, stemming from changes in the allocation of demand, 
Although the traditional Keynesian multiplier analysis takes a macroeconomic approach, as opposed to the basically microeconomic view of the elasticities approach, it implicitly assumes that the central bank prevents the continuous change in money balances implied by a persistent surplus or deficit in the balance of payments from feeding back onto the economy ${ }^{36}$ However, Prais has shown that the effects of changing money balances can be incorporated simply into the rigid-price multiplier framework, yielding an automatic income-adjustment mechanism for the elimination of a payments imbalance instead of the price-adjustment mechanism typically employed in monetary-approach models. ${ }^{37}$ The results differ, of course, from those of full global monetarism: under its assumptions equilibrium will always be reached at the full-employment level, but the incomeexpenditure equilibrium and external balance achieved in the multiplierplus-money approach would only accidentally be at full employment.

A number of authors who use the general-equilibrium monetary view to analyze policies affecting the balance of payments have expressed their models in a way that reveals the essential complementarity of the three approaches. As already noted, the monetary approach can be characterized as a kind of absorption approach in which the relation between desired and actual money stocks determines absorption relative to income. If a monetary model of the sort described earlier is expanded to incorporate two goods, and thus relative prices, it will, of course, reveal that the effects of monetary-induced changes in absorption on relative prices (and thus on

which in turn generate multiplier effects. See, for example, Meade, chap. 15, and Johnson, "Monetary Theory of Balance-of-Payments Policies."

36. This is not true of J. E. Meade, who included the money supply as well as the interest rate in his model. He then, however, assumed that monetary policy was either "Keynesian neutral" (maintained a constant rate of interest) or such as to ensure "internal balance." Either of these assumptions makes the money supply adapt passively to changes in the demand for it or to the policy requirements of internal balance, thus eliminating the influence of the money supply and the interest rate on the effect of a devaluation. See S. C. Tsiang, "The Role of Money in Trade-Balance Stability: Synthesis of the Elasticity and Absorption Approaches," in Caves and Johnson, eds., Readings in International Economics, pp. 391-92.

37. S. J. Prais, "Some Mathematical Notes on the Quantity Theory of Money in an Open Economy," International Monetary Fund Staff Papers, vol. 8 (May 1961), pp. 212-26. A similar incorporation of monetary effects into the elasticities approach, via a simple arithmetic example, is given in Arnold Collery, International Adjustment, Open Economies, and the Quantity Theory of Money, Princeton Studies in International Finance 28 (Princeton University, International Finance Section, 1971), pp. 22-24. 
the amount of reallocation required) depend on the magnitudes of the relevant elasticities. ${ }^{38}$

Many of the recent analytical refinements have emerged from this spelling out of the assumptions underlying alternative approaches, stimulated by the global-monetarist challenge and the responses to it. These improvements include the recognition that the partial-equilibrium assumptions underlying microeconomic analysis are inadequate to such fundamentally macroeconomic problems as devaluation-that, specifically, it is essential to make explicit the behavioral assumptions for all markets in a macroeconomic system, including the one eliminated from the solution set by Walras' law. They include, too, the now obvious but long-ignored point that exchange rates represent the relative prices of national moneys, which will correspond to the relative prices of national goods, or the terms of trade, only under very special assumptions. Since money is a financial asset, it follows logically that exchange rates should be determined (partly or wholly) in asset markets rather than entirely in product markets. Finally, there has emerged a new sensitivity to distinguishing between the impact and long-run effects of particular disturbances, and to the importance that different specifications of the adjustment mechanism in particular markets may have in determining impact effects and the dynamic adjustment path to stationary-state equilibrium. Today these insights are so widely accepted as to be considered obvious, and they are incorporated into virtually every model analyzing the balance of payments, the exchange rate, or, indeed, the impact of a wide variety of policies in an open economy. As a result, it is frequently difficult to draw the line-to tell where the "soft monetarists" leave off and the "eclectic Keynesians" begin. ${ }^{39}$

\section{DIFFERING IMPLICATIONS FOR POLICY}

This blurring of distinctions and reconciliation of alternative approaches have taken place, however, at the level of formal models published in schol-

38. See Rudiger Dornbusch, "Alternative Price Stabilization Rules and the Effects of Exchange Rate Changes," Manchester School, vol. 43 (September 1975), pp. 275-92, and Alexander K. Swoboda, "Monetary Approaches to the Transmission and Generation of Worldwide Inflation" (paper presented at the Brookings Conference on Worldwide Inflation, Washington, D.C., November 1974; processed).

39. The terminology is from Alan S. Blinder and Robert M. Solow, "Analytical Foundations of Fiscal Policy," in Blinder and others, The Economics of Public Finance (Brookings Institution, 1974), p. 58. 
arly journals and read by a small group of specialists. At the level of policymaking, and of public discussion conducted in the daily, weekly, and monthly media of news and opinion, the implications of global monetarism and of conventional Keynesian analysis are widely disparate. As a result of distillation and simplification, the nonspecialist sees the global-monetarist focus on long-run effects, on equilibrium analysis, on the stabilizing forces inherent in private-market behavior, and on price stability as crucially different in substance and policy implications, rather than merely in emphasis, from the Keynesian stress on the short and medium run, on disequilibrium analysis, on active government stabilization policy, and on full employment.

As was noted at the beginning of this paper, perhaps the most startling implication of global monetarism is its direct challenge to the conventional view that monetary policy is (along with fiscal policy) a primary instrument for stabilizing the aggregate level of domestic economic activity, while the exchange rate is the major policy tool available for altering the balance of payments. In the eyes of the global monetarists, the endogeneity of the money supply in an open economy and the requirement for money-market equilibrium in stock rather than flow terms together imply that the pursuit of domestic objectives by altering the domestic component of the money supply will be frustrated by an offsetting change in the international component through reserve flows. Further, a shift in the exchange rate can affect the balance of payments only to the extent that it alters the demand for money relative to the supply, and at that only transitorily, over the period required for the restoration of money-market equilibrium. If one adds a third assumption-that perfect arbitrage exists across national boundaries in both commodity and capital markets-the processes just described will operate promptly, rather than over a relatively long term, thus depriving monetary policy of the ability to affect the domestic economy even in the short run.

In arguing that exchange-rate changes are both ineffective and unnecessary for the achievement of payments equilibrium, global monetarism turns its back on the father of modern monetarism, Milton Friedman, who was probably the earliest, best-known, and most persistent supporter of flexible exchange rates in the postwar period. The question at issue is whether the domestic money supply is best regarded under pegged rates as an endogenous or exogenous (policy) variable. Viewing the money supply as a variable under the control of the national monetary authority, even under 
pegged rates, Friedman supports exchange-rate flexibility as a means of eliminating payments imbalances that would otherwise arise from divergent national monetary policies (or random real disturbances) without interfering with freedom of international transactions and thus global efficiency. ${ }^{40}$ The global monetarists, however, argue that the requirements for money-market equilibrium ensure the elimination of payments disequilibrium even under fixed exchange rates, and that such a regime is to be preferred on welfare grounds because it makes international risk-pooling possible and bestows the efficiency advantages associated with the existence of international money. ${ }^{41}$

Retaining the fundamental tenets of the monetary approach (the nonsterilization assumption and the requirement of long-run stock equilibrium in the money market), but relaxing the assumptions of global monetarism by (a) permitting monetary changes to affect real variables in the short run and (b) assuming imperfect substitutability across national boundaries in either product or capital markets, ${ }^{42}$ restores some short-run independence for domestic policy even under fixed exchange rates. But the long-run equilibrium results are the same: the assumptions of the monetary approach are sufficient to ensure the eventual restoration of proportionality between changes in the money stock and in the price level, and the worldwide convergence of national inflation rates. ${ }^{43}$

Under the assumptions of the monetary approach, devaluation obviously cannot be used to bring about a permanent alteration in a country's balance

40. Friedman, "Case for Flexible Exchange Rates," p. 414.

41. Arthur B. Laffer, "Two Arguments for Fixed Rates," and Robert A. Mundell, "Uncommon Arguments for Common Currencies," in Harry G. Johnson and Alexander K. Swoboda, eds., The Economics of Common Currencies (Oxford: Allen and Unwin, 1973). Note that the risk-pooling argument is valid only "if it can be assumed that monetary policy errors and output variations are truly random and independent of the exchange rate regime chosen." Johnson, "Monetary Approach . . . A Diagrammatic Analysis," p. 229.

42. An alternative assumption would be the existence of nontraded goods and assets. See Rudiger Dornbusch, "Real and Monetary Aspects of the Effects of Exchange Rate Changes," in Robert Z. Aliber, ed., National Monetary Policies and the International Financial System (University of Chicago Press, 1974).

43. Branson points out that this convergence is also implied by a Keynesian trademultiplier model that incorporates a price Phillips curve. William H. Branson, "Monetarist and Keynesian Models of the Transmission of Inflation," American Economic Review, vol. 65 (May 1975), pp. 115-19. Gordon notes, however, that the monetary approach adds new channels for international transmission of inflation to the traditional ones. Robert J. Gordon, "Recent Developments," p. 39. 
of payments. Unless all markets are assumed to adjust instantaneously, however, devaluation will cause a temporary improvement in the payments balance during the period of transition to the new equilibrium, and may thus retain its usefulness as a policy tool under certain circumstances. Specifically, it may be used either to achieve a one-shot increase in a country's stock of international reserves, or to finance a temporary budget deficit through money creation, without causing a temporary deterioration in the balance of payments. ${ }^{44}$ Similarly, revaluation may be used to cause a temporary deterioration in a country's payments balance (and thus a decrease in its reserve stock) and a one-time reduction in its price level relative to that in the rest of the world.

Furthermore, whereas the monetary approach generally considers the effects of a devaluation on an economy that is initially in long-run equilibrium, exchange-rate changes are in fact generally undertaken from a position of short-run disequilibrium. In this context, an exchange-rate change may be justified as a faster way to eliminate disequilibrium than reliance on the monetary adjustment mechanism under fixed rates. The question arises, however, as to how a payments disequilibrium can occur in the first place; Johnson notes that "an appropriate rationale for introducing exchange-rate changes can be introduced by positing limitations on the scope for use of ordinary monetary policy." He adds, however, "that if the initial deficit or surplus that prompted the devaluation or revaluation under consideration was due to the inability of the monetary authority to pursue respectively a sufficiently contractionary or sufficiently expansionary monetary policy, the exchange rate change can only lead back transitorily to balance-of-payments equilibrium, and the deficit or surplus will recur (and be chronic) unless the relevant weakness of the power of conventional monetary policy is corrected." 45

\section{IMPLICATIONS FOR ACCOUNTING}

The monetary approach to balance-of-payments analysis has unconventional implications also for the form and structure of balance-of-payments accounting-in particular, for the type of "balances" that have analytical significance. As has already been mentioned, the Keynesian approach fo-

44. Dornbusch refers to this as the "capital levy aspect of a devaluation." See "Real and Monetary Aspects," p. 75.

45. "Monetary Approach ... A Diagrammatic Analysis," pp. 226-27. 
cuses on the balance on goods and services, which corresponds to the "net exports" sector in the national income accounts. When the Keynesian approach is expanded to incorporate a flow theory of international capital movements, the corresponding accounting framework would logically include a balance on goods and services (the remaining item in the balance on current account, unilateral transfers, is something of an anomaly, which does not fit easily into any sectoral analytical framework), a balance on securities (the "capital account"), and a residual and offsetting reserve balance which includes the means of payment to finance the other two accounts. The optimal division among different balances can be debated endlessly, and the balances themselves endlessly proliferated, but the underlying principle is the same: there is a net balance that corresponds logically to each category of transactions for which there is a separate explanatory theory, and transactions that do not fall into any of the explained categories belong "below the line," as accommodating items that finance the others. ${ }^{46}$ Thus, Keynesians analyze the balance of payments from the "top down."

The monetary approach, in contrast, focuses primarily on the money market and regards the relationship between the (stock) demand for and supply of money as the critical determinant of the balance of payments. The appropriate analysis is thus from the "bottom up," focusing on changes in the balance on official-reserve transactions and frequently ignoring changes in the composition of the balance of payments among the nonmonetary items above the line. Specifically, whether a disequilibrium in the money market is eliminated through the current or the capital account is generally indeterminate, ${ }^{47}$ so that such subbalances are not of major analytical significance. But international flows of reserves, far from being a mere residual, reflect the very disequilibrium in the money market that moves the whole system, since "it is primarily through their effects on the money supply that [international] transactions have any appreciable impact on aggregate economic activity." ${ }^{48}$ In fact, any disturbance in international trans-

46. For an outstanding example of this approach to balance-of-payments analysis and forecasting, see Walter S. Salant and others, The United States Balance of Payments in 1968 (Brookings Institution, 1963).

47. For a "monetary approach" model that makes explicit the separate impact of disturbances on the current and the capital accounts, see Frenkel and Rodriguez, "Portfolio Equilibrium."

48. Donald S. Kemp, "Balance-of-Payments Concepts-What Do They Really Mean?" Federal Reserve Bank of St. Louis, Review, vol. 57 (July 1975), p. 21. 
actions that does not cause disequilibrium in the monetary account is not, in this view, a source of payments imbalance at all, since it must have been offset either by independent and coincidental changes or by induced changes elsewhere in the accounts. ${ }^{49}$

In a gold-standard world, without any reserve currencies, the balance that measures international flows of reserves, and hence the effect of international transactions on the domestic money supply, would correspond to the balance on official-reserve transactions, as measured in the U.S. balance-of-payments statistics. This would then be the crucial-indeed, the only meaningful - balance for the monetary approach, since it would represent both the pressures on the dollar from disequilibrium in the distribution of the world's money supply and the operation of the automatic adjustment mechanism to restore worldwide equilibrium in the money market. In a world of reserve currencies, however, a country such as the United States may, by making additional reserves available, affect the money supplies of other countries, without a corresponding impact on its own. Thus, the balance on official-reserve transactions of the United States includes not only transactions that alter some components of the monetary base (that is, changes in U.S. official holdings of gold and foreign currencies or in foreign deposits at Federal Reserve Banks), but also a variety of transactions that have no such impact (such as changes in holdings of special drawing rights, in the U.S. net position with the International Monetary Fund, or in holdings of U.S. interest-bearing assets by toreign official agencies). Yet the "balance on money account," or transactions affecting the monetary base, which the monetary approach regards as the only appropriate measure of net exchange pressure on a reserve currency under fixed exchange rates, is not among the numerous "balances" now calculated in the official U.S. balance-of-payments statistics. ${ }^{50}$

The proponent of a Keynesian approach to payments adjustment argues, in contrast, for the exclusion of international transactions in short-term liquid assets from his aggregate balance-of-payments model because "gross reserve positions and the distribution of the stock of international short-term assets among nations have little effect upon international economic policy." See H. Peter Gray, An Aggregate Theory of International Payments Adjustment (Macmillan, 1974), p. 36.

49. William J. Fellner, "'Monetary' versus 'Monetarist' Theories: Drawing the Distinction," in Clark and others, Effects of Exchange Rate Adjustment.

50. Kemp, in "Balance-of-Payments Concepts," p. 22, calculates such a balance for 1974. 


\section{The Dual of the Monetary Approach: The Asset Approach to Exchange-Rate Determination}

All of the discussion so far has assumed a regime of fixed-or peggedexchange rates. Only under such a regime do balance-of-payments disequilibrium and its adjustment become policy issues. But the analytical approach has its counterpart, or dual, in a world of freely flexible exchange rates: the asset-market approach to exchange-rate determination. The fundamental symmetry of the long-run stock-equilibrium implications of the two approaches can be seen in equations 1 through 6 . These equations can be used to solve for an endogenous exchange rate with only one modification: since the exchange rate now varies to maintain payments equilibrium throughout, reserve movements are always zero and the national money stock in each country becomes an exogenous variable under the control of its monetary authority. The long-run equilibrium exchange rate is then determined by the relationship between the price levels in the two countries (equation 2), each of which is in turn a function of the relationship between the desired and the actual stock of national money (equation 1). ${ }^{51}$ (Note, incidentally, that a regime of flexible exchange rates implies two distinct national moneys, separated by the changing price relationship between them, and eliminates any meaningful concept of a world money stock.) Despite the long-run symmetry between the monetary approach under pegged rates and its flexible-rate analogue, the adjustment process is quite different in the two regimes. Under fixed exchange rates, quantities adjust gradually, in the form of reserve flows, to bring about equality between the actual stock of money and the desired level of real balances. Under flexible

51. The exchange rate will also be determined by the requirements of asset-market equilibrium in the short run, even if limitations on commodity arbitrage are assumed to permit the emergence of temporary deviations from the purchasing-power-parity condition of equation 2 . In this case, the condition for money-market equilibrium, $L=M$, must be rewritten (for the home country, and analogously for the foreign country) as

$$
\frac{M}{w \bar{P}+(1-w) \bar{P}^{*} e}=k \bar{y},
$$

where $w$ is a weight, and $M$ determines $e$ directly. For a more detailed discussion of the monetary approach to exchange-rate determination in the short run versus the long run, see Rudiger Dornbusch, "The Theory of Flexible Exchange Rate Regimes and Macroeconomic Policy," Scandinavian Journal of Economics (formerly Swedish Journal of Economics) (forthcoming, 1976). 
rates, with the nominal quantity of money fixed in each country, changes in the valuation of the stock through changes in the exchange rate bring about instantaneous full stock adjustment in the money market..$^{52}$

Unfortunately, this stripped-down model is inadequate to generate some of the more interesting policy implications of the asset approach to exchange-rate analysis. Two extensions, in particular, are critical: One is the specification of assumptions regarding the formation of expectations. $\mathrm{Ob}-$ viously, expectations play no role in the determination of the stationarystate equilibrium itself, since they must be static under that condition. But they will significantly influence the dynamic adjustment path in a model in which the exchange rate is determined by the stock-equilibrium conditions appropriate to asset markets rather than by the equality between flow supply and flow demand that characterizes commodity markets. The possible explanations of how expectations are formed are numberless, so that a wide variety of conclusions regarding the impact effect of exchangemarket disturbances and the nature of the dynamic adjustment path can emerge within the general framework of the asset-market approach. It turns out, however, that several widely used simple models of expectations formation yield one common result: when there are adjustment lags, the impact effect of a disturbance on the exchange rate will exceed the long-run equilibrium effect; that is, the exchange rate will initially overshoot in response to a disturbance, and then retreat gradually toward its new long-run equilibrium value along the dynamic adjustment path. ${ }^{53}$

A second important extension of the model is the introduction of a second financial asset-bonds-and, with it, the rate of interest. Given this additional market, the long-run condition for stationary-state equilibrium in asset markets requires that the current-account balance be equal to zero, so that the total stock of wealth is unchanging, and that international flows of capital thus be zero as well. ${ }^{54}$ This particular extension makes possible the analysis of the effects of fiscal as well as monetary policy. One implication of this extended model, for example, is the critical role played by inter-

52. Frenkel and Rodriguez, "Portfolio Equilibrium," and Pentti J. K. Kouri, "The Exchange Rate and the Balance of Payments in the Short Run and in the Long Run: A Monetary Approach," Scandinavian Journal of Economics (forthcoming, 1976).

53. See, for example, ibid.

54. The portfolio-balance requirements could also be met in principle by what Mundell calls quasi-equilibrium, in which the government deficit (which pumps financial assets into the private sector) exactly equals the trade deficit (which drains such assets out of that sector). See Mundell, International Economics, p. 226. 
national capital mobility in the relative efficacy of fiscal policy under different exchange-rate regimes. Applying the conventional IS-LM analysis to an open economy without capital mobility, one can easily demonstrate that fiscal policy has a greater impact on domestic economic activity under flexible than under fixed rates, because the exchange rate will always move so as to prevent any reduction in the domestic multiplier effect via leakage through the trade balance. But the domestic impact of fiscal policy falls as capital mobility increases until, with fully integrated capital markets, fiscal policy becomes totally ineffective as a domestic stabilization tool. Any expansionary measure, such as increasing net government expenditures (with a given money supply), will put upward pressure on the rate of interest. The resulting inflow of capital will cause an appreciation of the currency, and the resulting deflationary impact on the trade balance will exactly offset the initial multiplier effect of fiscal policy on domestic income. With a given liquidity-preference schedule and an exogenously frozen interest rate, the requirements of money-market equilibrium will prevent any change in domestic income without a change in the money supply, and "global crowding out" will render fiscal policy useless. ${ }^{55}$

One of the arguments frequently advanced in favor of flexible exchange rates is that they enable countries to insulate themselves from monetary disturbances originating abroad, bottling up such disturbances in their country of origin. And, indeed, in the simple model of equations 1-6, this is the case. An increase in the foreign money supply, which under fixed rates would lead ultimately to increases in the domestic money supply and price level equal to those abroad, would, under flexible rates, be offset by an appreciation of the domestic currency in response to the incipient surplus arising from the foreign excess supply of money; and that appreciation would leave the domestic money supply, price level, and all domestic real variables unchanged.

Once interest rates and internationally mobile securities are introduced into the picture, however, the insulation provided by flexible exchange rates becomes incomplete. Now an increase in the foreign money supply will lower interest rates not only in the country where the disturbance originates but in the home country as well. With an unchanged domestic money stock, an upward-sloping LM curve requires that the lower interest rate be accom-

55. See Whitman, Policies for Internal and External Balance, pp. 20-21. The speed with which this "crowding out" occurs depends on how rapidly trade flows are assumed to adjust to changes in the exchange rate. 
panied by a lower level of income if money-market equilibrium is to be maintained. Flexible exchange rates do not abolish interdependence in a world of capital mobility. ${ }^{56}$ Indeed, Cooper has pointed out that the impact of certain types of disturbances abroad may actually be aggravated rather than softened or eliminated by flexibility of exchange rates. As an example, he cites an exogenous shift in asset preferences that increases the foreign demand for domestic securities at a constant rate of interest. The result would be an appreciation of the domestic currency, leading to a currentaccount deficit, and a reduction of domestic aggregate demand and income (as well as, in a two-commodity model, a reallocation of resources away from tradable and toward nontradable goods). ${ }^{57}$ Thus, the insulation of countries from disturbances originating abroad provided by freely flexible exchange rates depends heavily on the type of disturbance assumed to dominate in the international arena.

In a world of rate flexibility, exchange-market disequilibrium is measured, not by any payments "balance," but rather by changes in the effective (that is, weighted) exchange rate of the dollar vis-à-vis other countries. But here, again, the asset-market approach views such changes as reflecting disequilibrium in the distribution of the world's stock of money (or financial assets in general), in contrast to the conventional Keynesian approach, which is more apt to analyze them in terms of flow disequilibrium in the goods or securities markets..$^{58}$ In a world of managed floating, market pressures on a currency are reflected both in the net international flow of reserves and in movements in the effective exchange rate, although no one has yet developed a single composite unit to measure empirically the total pressure reflected through both these channels.

Finally, the monetary approach implies a definition of "international policy coordination" in a world of managed floating somewhat different from that of conventional analysis. It is widely recognized that, in order to avoid inconsistency among exchange-rate targets under such a regime and a resulting disorder similar to the competitive depreciations of the 1930s,

56. Arnold Collery, "Macro-economics in an Open Economy under PurchasingPower Parity," in Aliber, ed., National Monetary Policies, and Rudiger Dornbusch, "Flexible Exchange Rates, Capital Mobility and Macroeconomic Equilibrium," in Classen and Salin, eds., Recent Issues in International Monetary Economics.

57. Richard N. Cooper, "Monetary Theory and Policy in an Open Economy," Scandinavian Journal of Economics (forthcoming, 1976).

58. For an empirical evaluation of the equilibrium dollar-mark exchange rate within the monetary framework, see Citibank Money International, vol. 3 (April 30, 1975). 
rules for intervention in the exchange markets are essential. ${ }^{59}$ The monetary approach stresses, however, that rules for intervention are fundamentally inadequate to the problem of inconsistent targets, since there is more than one means to pursue such targets. "A government can cause its currency to depreciate almost as well by having its central bank buy domestic bonds as by having it buy foreign currency." ${ }^{\circ}$ On the other side, the recent history of managed floating is replete with instances of countries supporting their currencies indirectly, through foreign borrowing, rather than directly in the exchange markets. What is crucial is the relationship between the demand for and the supply of money, not whether the money is created by buying (or selling) domestic or foreign assets. Thus, true policy coordination to avoid inconsistent target setting requires, in the monetary approach, not rules governing intervention in the exchange markets, but rules guaranteeing the compatibility of national monetary policies, and fiscal policies to the extent that they are financed by money creation or affect the demand for money. International coordination as defined by the monetary approach is much more demanding, and much more restrictive of national economic sovereignty, than the limited rules for exchange-market intervention that are conventionally regarded as the means of avoiding inconsistent and thus destabilizing exchange-rate targets among nations. ${ }^{61}$

\section{Some Empirical Issues Unresolved}

In any attempt to evaluate the contribution of global monetarism and the monetary approach to the analysis of current policy issues, certain obvious empirical questions arise.

59. The question of rules for intervention was a major topic in the IMF's discussions of international monetary reform. See Committee on Reform of the International Monetary System and Related Issues (Committee of Twenty), International Monetary Reform: Documents of the Committee of Twenty (International Monetary Fund, 1974), annex 4 , sec. B.

60. Michael Mussa, "The Exchange Rate, the Balance of Payments, and Monetary and Fiscal Policy under a Regime of Controlled Floating," Scandinavian Journal of Economics (forthcoming, 1976).

61. Furthermore, a recent study concludes that "the systematic use of sterilization policies by two or more countries . . . may lead to explosive reserve flows and, therefore, to the breakdown of the system." Paul De Grauwe, "The Interaction of Monetary Policies in a Group of European Countries," Journal of International Economics, vol. 5 (August 1975), p. 225. 


\section{LAW OF ONE PRICE}

For one thing, how realistic is the assumption of the "law of one price," or of a high degree of substitutability across national boundaries in both commodity and financial-asset markets? ${ }^{62}$

The assumption really takes two forms, depending on the length of run and the adjustment mechanism involved. The weaker form is that of the purchasing-power-parity concept, which asserts that, over long periods of time (decades, for example), changes in exchange rates tend to offset-or be offset by-changes in relative price levels. This concept has stood up well to empirical verification for long periods, although there is ample evidence of substantial short-run deviations. ${ }^{63}$ The "law of one price" asserts substantially more, however, than a long-run tendency toward purchasingpower parity among countries. In particular, it asserts that high elasticities of substitution prevail among countries for most tradable goods and financial assets, and that, because world markets are highly integrated, a single price must prevail in all markets for goods and assets that are close substitutes for one another. This view implies that competitive forces will quickly and directly eliminate changes in relative prices stemming from exchangerate changes by offsetting changes in domestic prices. Although recent studies indicate a very high degree of market integration and international substitutability for primary commodities, other investigations conclude that the close-substitutes hypothesis fails to hold for manufactured goods in general for the time periods examined and at the levels of aggregation employed; that is, "the relative dollar prices of industrial outputs do seem

62. Although Frenkel has argued forcefully for "the irrelevance of commodity arbitrage" in the asset view of exchange-rate determination (and thus, by extension, in the monetary approach to balance-of-payments analysis), the fact remains that this assumption is common to many of the models of this genre. And it is certainly essential for the derivation of many of the strong policy implications of full-fledged global monetarism. See Jacob A. Frenkel, “A Monetary Approach to the Exchange Rate: Doctrinal Aspects and Empirical Evidence," Scandinavian Journal of Economics (forthcoming, 1976).

63. On the first point, see Harry J. Gailliot, "Purchasing Power Parity as an Explanation of Long-Term Changes in Exchange Rates," Journal of Money, Credit and Banking, vol. 2 (August 1970), pp. 348-57, and Arthur B. Laffer, "The Phenomenon of Worldwide Inflation: A Study in International Market Integration," in David I. Meiselman and Arthur B. Laffer, eds., The Phenomenon of Worldwide Inflation (American Enterprise Institute, 1975), pp. 27-52. On the second point see, for example, Ronald I. McKinnon, "Floating Exchange Rates, 1973-74: The Emperor's New Clothes," Journal of Monetary Economics (supplement, forthcoming, 1976). 
to change substantially and permanently [over the six-year period 1968-73] when exchange rates change." ${ }^{44}$ Estimates made in two recent studies imply that the United States can expect to retain for some time over half of a change in the effective exchange rate in the form of a relative price advantage for manufactured exports. ${ }^{65}$ Similarly, there is empirical evidence that, despite increasing integration of financial markets, investors do not regard foreign and domestic long-term financial assets as perfect substitutes for one another.$^{66}$ For short-term money-market assets, in which international integration has proceeded the furthest, the evidence on the degree of independence retained by national interest rates is somewhat inconclusive. ${ }^{67}$

\section{STERILIZATION}

Another empirical question-one that is central not only to the strong conclusions of global monetarism but also to the weaker ones of the monetary approach-is whether governments can and do engage in a "deliberate nullification" of the impact of a payments imbalance on the domestic supply of money. By now, a considerable literature has arisen from empirical investigations of the extent to which various nations at various times have successfully "sterilized," or offset the effects of a payments imbalance on the domestic monetary base, and also of the extent to which the domestic impact of monetary policy is offset by international capital flows. ${ }^{68}$

64. Peter Isard, "The Price Effects of Exchange Rate Changes: Some Evidence from Industry Data for the United States, Germany, and Japan, 1968-73," in Clark and others, Effects of Exchange Rate Adjustment.

65. J. R. Artus, "The Behavior of Manufactured Export Prices," and S. Y. Kwack, "The Effects of Foreign Inflation on Domestic Prices and the Relative Price Advantage of Exchange Rate Changes," in ibid.

66. Herbert G. Grubel, "Internationally Diversified Portfolios: Welfare Gains and Capital Flows," American Economic Review, vol. 58, pt. 1 (December 1968), pp. 12991314.

67. See, for example, Richard J. Herring and Richard C. Marston, "The Monetary Sector in an Open Economy: An Empirical Analysis for Canada and Germany," Working Paper 7-74 (University of Pennsylvania, Rodney L. White Center for Financial Research, 1974; processed), and Richard C. Marston, American Monetary Policy and the Structure of the Eurodollar Market, Princeton Studies in International Finance 34 (Princeton University, International Finance Section, 1974).

68. See, for example, Victor Argy and Pentti J. K. Kouri, "Sterilization Policies and the Volatility in International Reserves," and Warren D. McClam, "Monetary Growth and the Euro-currency Market," in Aliber, ed., National Monetary Policies; Herring and Marston, "Monetary Sector in an Open Economy"; Pentti J. K. Kouri, "The Hypothesis of Offsetting Capital Flows: A Case Study of Germany," Journal of Mone- 
While these studies indicate that at least some degree of sterilization has been or could be undertaken in the short run by the countries surveyed, they also suggest a wide range of experience, even among industrialized nations. Considerable evidence indicates that Japan, for example, has in recent years been able to sterilize most of the balance-of-payments impact on its monetary base; in Germany, conversely, the money supply has been much closer to being endogenously determined even in the short run. At least one instance of "perverse" behavior-that is, reinforcement rather than neutralization of the balance-of-payments impact on the monetary base-has been suggested by the data. Besides indicating wide variations in experience among countries, the studies conducted so far have all been subject to serious problems of simultaneity, revealing the need for much more work to develop better empirical tests of the general applicability of the monetary approach and its policy implications.

In contrast to this general uncertainty, the United States is clearly a special case, for which the money supply is primarily an exogenous variable, controlled by the monetary authorities, rather than the endogenous variable postulated by the monetary approach. This is partly a simple matter of size; as Swoboda has noted, the monetary approach implies that, under fixed exchange rates and with money multipliers assumed equal in all countries, open-market purchases of securities cause reserve losses that are inversely proportional to the country's relative economic size and thus expansions in the domestic money supply in direct proportion to that size. ${ }^{69}$ To put it another way, even though the monetary approach implies that no country can alter its share of the world money stock through monetary policy, the sheer size of the U.S. share ensures its ability to alter the total magnitude of the world money stock and thus the size of its own money supply. For an economy as large as the United States, monetary policy retains a domestic impact, even under fixed exchange rates in an integrated world economy.

tary Economics, vol. 1 (January 1975), pp. 21-39; Norman C. Miller and Sherry S. Askin, "Domestic and International Monetary Policy," Journal of Money, Credit and Banking (forthcoming, 1976); and Niels Thygesen, "Monetary Policy, Capital Flows and Internal Stability: Some Experiences from Large Industrial Countries," Swedish Journal of Economics, vol. 75 (March 1973), pp. 83-99, as well as other studies cited in the aforementioned.

69. Relative economic size is measured in terms of the country's share of the world's money supply. See Alexander K. Swoboda, "Gold, Dollars, Eurodollars and the World Money Stock” (Geneva: Graduate Institute of International Studies, 1974; processed), p. 9. 
In addition to this sort of indirect control that a large economy has over its own money supply, it can also exercise direct control to the extent that it can effectively sterilize the impact of the balance of payments on its domestic money supply. ${ }^{70}$ Presumably, the capacity to sterilize is partly a function of a country's economic size, as well as of the size of its stock of international reserves. But the status of the United States as a reserve-currency country is probably even more important than its weight in the world economy in enabling it to neutralize the feedback from the balance of payments to the domestic money supply. As noted above, a measured deficit in the balance of payments of a reserve-currency country may be accompanied, not by any loss of primary reserve assets, but rather by an increase in certain kinds of liabilities to foreign monetary authorities. The creation of these liabilities will often result in partial or full automatic sterilization of the balance-of-payments impact on the U.S. money supply, without any deliberate action on the part of the U.S. monetary authorities. ${ }^{71}$ Given both its size and its reserve-currency position, it is hardly surprising that the sterilization coefficients estimated for the United States in empirical studies have generally not differed significantly from unity. For the United States, the domestic money supply remains an exogenous policy variable even under fixed exchange rates and in the face of increasing international integration of markets.

Effective "deliberate nullification" in the case of the United States-and perhaps other countries, as their currencies are increasingly held as reserve assets-by no means negates all the policy implications of the monetary approach. Specifically, it does not disturb the postulated relationship between domestic monetary policy and the balance of payments, nor the channels by which domestic disturbances in the sterilizing country are transmitted to the rest of the world. It also introduces three important changes into the analysis: (1) It restores monetary policy as a policy variable operating on the domestic economy, under fixed as well as flexible exchange rates. (2) It destroys the symmetry whereby a given amount of domestic money creation has the same impact on the world money supply, regardless of the origin of the disturbance; asymmetries are introduced because low-powered money in a reserve-currency country becomes high-

70. Swoboda notes that a successful sterilization policy in one country gives that country an effective weight of one in the determination of the world's money stock (ibid., p. 10). The same point is noted in Girton and Roper, "Monetary Model."

71. Swoboda, "Gold, Dollars, Eurodollars," pp. 15-18. 
powered, or base, money in other countries. (3) It renders the monetary policy of all countries other than the reserve-currency country totally ineffective and ensures that they bear the full burden of the classical adjustment process. ${ }^{72}$ In addition, in the case of a reserve-currency country, the a priori relationship between changes in the money supply and the balance of payments is negative, as opposed to the positive relationship that prevails in the case of non-reserve-currency countries, whose money supplies are indeed endogenous. Finally, note that no more than one country in the system can sterilize completely the impact of payments imbalances on its money supply without destabilizing the system as a whole. ${ }^{73}$

In addition to efforts to estimate sterilization coefficients, a few more comprehensive attempts have been made to test the monetary approach to the balance of payments, either alone or by comparing it with alternative approaches-for example, to the analysis of the balance-of-payments impact of devaluation..$^{74}$ Such tests are hampered by a number of technical difficulties, chief among them the fact that direct estimation of the balanceof-payments equation implied by the monetary approach involves the estimation of an accounting identity rather than a true behavioral relationship. Thus, only indirect tests of some of the implications of the monetary approach are legitimate, and these are inevitably arbitrary and subject to varying interpretations. Furthermore, no investigator has combined all the variables associated with the various approaches to devaluation in a single equation, as would be required for an appropriate comparison of their rela-

72. For an analysis of the gold-exchange standard along these lines, see Jacques Rueff, Balance of Payments (Macmillan, 1967).

73. See De Grauwe, "Interaction of Monetary Policies."

74. Among such studies are B. B. Aghevli and M. S. Kahn, "The Monetary Approach to Balance of Payments Determination: An Empirical Test," in International Monetary Fund, The Monetary Approach to the Balance of Payments: An Anthology (forthcoming, 1976); B. Brittain and Sri Kumar, "Monetary Balance of Payments Theory: Implications and Tests," Working Paper (First National City Bank, 1974; processed); Thomas J. Courchene, "The Price-Specie-Flow Mechanism and the Gold-Exchange Standard," in Johnson and Swoboda, eds., Economics of Common Currencies; Hans Genberg, "An Empirical Comparison of Alternative Models of Currency Devaluation"' (Geneva: Graduate Institute of International Studies, November 1974; processed); Wolfgang Kasper, "The Emergence of an Active Exchange-Rate Policy-Some Quantitative Lessons," in Kasper, ed., International Monetary Experiments and Experiences, Papers and Proceedings of the Symposium on International Monetary Problems, Port Stephens, Australia, August 1975 (Canberra, Australia: forthcoming, 1976); Pentti J. K. Kouri and Michael G. Porter, "International Capital Flows and Portfolio Equilibrium," Journal of Political Economy, vol. 82 (May/June 1974), pp. 443-67. See also the various empirical studies in Frenkel and Johnson, eds., Monetary Approach. 
tive explanatory power. In any case, apart from these technical problems, the various efforts to test the monetary approach directly have proved inconclusive, with estimated coefficients turning out significant with the correct sign in some cases but not in others, and with the estimated magnitudes of the coefficients frequently differing significantly from their a priori values. At present, both supporters and critics of the monetary approach can find considerable ammunition in empirical results. As Blinder and Solow have noted with respect to the various empirical tests of the competing hypotheses of monetarism and Keynesianism in a closed-economy context, "The issue is simply not to be settled by comparing goodness of fit of one-equation models that are far too primitive to represent any theory adequately."75

\section{MANAGED FLEXIBILITY}

Finally, one must ask whether the monetary approach —or, indeed, any existing balance-of-payments theory-is applicable to the international monetary framework within which the world now operates. The monetary theory is well defined for a world on the gold standard or even for a world of pegged exchange rates in which parities are changed infrequently. ${ }^{76}$ And it has an analogue - the asset approach to exchange-rate determinationfor a world of freely flexible exchange rates without government intervention. But the rules by which the monetary authorities conduct themselves, and the implications of those rules for the behavioral properties of a world of managed flexibility, have yet to be explored. The implicit assumption made by many analysts is that managed flexibility can be fully characterized as a situation "somewhere between" fixed and freely flexible rates, which can be formally incorporated by introducing a "combined" variable to represent pressure on the currency in the form either of reserve flows or of changes in the effective exchange rate. But certain anomalies in recent experience-such as the apparent failure of the worldwide demand for reserves to decline substantially with the greater flexibility of exchange rates - suggest that the behavioral characteristics of managed flexibility may be qualitatively different from those of a pegged-rate or freely flexible regime, rather than some simple average of the characteristics of the two limiting cases.

75. "Analytical Foundations," p. 65.

76. It does not encompass, however, any of the expectational or other dynamic effects of frequent changes in exchange rates. 


\section{Some Fundamental Issues in Political Economy}

Some significant issues in political economy arise in any attempt to evaluate the analytical contributions and policy relevance of the challenges to current orthodoxy that are the focus of this survey. In discussing the issues, two major distinctions between global monetarism and the monetary approach must be borne in mind. First, as an earlier section has emphasized, the monetary approach is only one of the three strands of assumptions that define global monetarism, along with the full-employment assumption and the "law of one price level" (or, in some models, the "small country" assumption). Second, whereas both global monetarism and the monetary approach tend to focus on the characteristics of the system in stationary-state equilibrium, adherents of the monetary approach generally recognize that such long-run tendencies are compatible with many specifications of impact effects and dynamic adjustment mechanisms; extreme global monetarism, on the other hand, tends to draw policy implications from the characteristics of long-run stock-equilibria, suggesting by implication that they are actually achieved rapidly enough to make the characteristics of the transition unimportant.

Indeed, this question-"How long is the long run?"-is critical to the applicability of stationary-state general-equilibrium analysis to policy issues. It is important for the positive economics of forecasting, because the more gradual is the approach to equilibrium, the more certain it is that disturbances and changes in behavioral parameters will impinge during that approach, deflecting the economy from its initial path to the new equilibrium, and the more difficult it becomes to estimate the ceteris paribus effect of a particular exogenous change. The question is significant for the normative economics of policy prescription as well, not simply because of the notoriously short time horizon of policymakers but, more fundamentally, because of the very real social costs that may be associated with disequilibrium states or with different adjustment mechanisms.

Thus, the factors that affect the speed of adjustment to equilibrium become important: the effectiveness of commodity arbitrage across international boundaries, the degree of capital mobility, the strength of realbalance effects, and the proportion of traded to nontraded goods in the economy. It makes no difference to the nature of the full-equilibrium state whether purchasing-power parity is thought to be established via perfect substitutability and international arbitrage, or is regarded as a monetary 
phenomenon independent of such arbitrage. But it does make a very substantial difference to the length of run implied for the adjustment process. To put the problem slightly differently, economists disagree relatively little about the long-run general-equilibrium characteristics of the economic system. But for the short run, when the system diverges either from some of the behavioral relations or from one or more equilibrium conditions, there is substantial disagreement about which relationships can be assumed to hold throughout and which not, about which markets can be assumed to be continuously in equilibrium and which not. And, the longer the "short run" is, the more important these divergences become in determining the policy implications of the competing approaches.

Closely related to the question of the length of run over which adjustment takes place is the question of whether the assumption of fundamental stability that underlies equilibrium analysis is valid. If the world is in fact subject to frequent disturbances and shifts in behavioral parameters, then the equilibrium model is not appropriate for policy analysis, nor is it obvious that a mode of analysis that always begins with equilibrium can yield meaningful answers for a system whose initial state is inevitably disequilibrium. Furthermore, a fundamental proposition of global monetarism (and, to a lesser extent of the monetary approach) is that strong self-corrective tendencies operate in the economic system. But disturbances may in fact be cumulative rather than self-correcting; Okun has argued that, in fact, "the [econometric] evidence of both Keynesian and monetarist models of economic activity suggests that we live in an economy of persistence, rather than self-correction."77

Implicit in the monetary approach to the balance of payments, which views it from the bottom up, focusing on changes in reserve stocks, ${ }^{78}$ is the

77. Arthur M. Okun, "Fiscal-Monetary Activism: Some Analytical Issues," $B P E A$, $1: 1972$, p. 147. More specifically, Meltzer argues that if the global-monetarist model (which he calls the Mundell model) is modified to incorporate fiscal policy, the fixedexchange-rate system is likely to be unstable. See Allan H. Meltzer, "The Monetary Approach to Inflation and the Balance of Payments: Theoretical and Empirical Contributions at the Leuven Conference," in Michele Fratianni and Karel K. Tavernier, eds., supplement to the journal, Kredit und Kapital, published in West Germany (forthcoming, 1976).

78. Harry Johnson argues that "the crucial distinction for the Yale School [of Keynesians] . . . is between the financial sector and the real sector (or between stock and flow analysis) rather than between the banking system and the rest of the economy (as various versions of the contemporary quantity theory would have it) . ..." Further Essays in Monetary Economics, p. 38. 
assumption that changes in the composition of the balance among the nonmonetary items "above the line" are irrelevant. By contrast, the Keynesian approach, which looks separately, from the top down, at the forces affecting each category of transactions grouped into a "balance," views the composition of the balance of payments as itself a relevant question for analysis and a legitimate concern of policy. The analytical and policy relevance of the composition of the balance of payments must be considered from two aspects. One is the stability of selected subbalances or categories of international transactions. In particular, the adjustment costs associated with reallocation of factors of production suggest that fluctuations in the goodsand-services account may well have a negative rather than a neutral impact on the economy even if offsetting changes in some other account prevent any net balance-of-payments effect. This view, certainly, is implicit in the persistent focus of Keynesian analysis on the goods-and-services account. The second aspect is whether different levels of particular subaccounts may have different welfare implications and therefore be a legitimate focus of analysis. Keynesians frequently argue, for example, that the persistence of unemployment and downward wage rigidity makes the goods-and-services account a legitimate instrument of full-employment policy. At a more sophisticated level, Williamson has recently used the tools of optimal-control theory to demonstrate that different combinations of current- and capital-account balances have different implications for international indebtedness and thus will trace out different growth paths of consumption. His analysis implies, furthermore, that only under very special assumptions will the dynamically optimal composition coincide with the composition that would be generated by a market-determined exchange rate. ${ }^{79}$ Thus, it would appear that both the Keynesian and the monetary approaches can be faulted in their handling of balance-of-payments composition. Keynesian analysis overlooks the interdependence among the various accounts through failure to incorporate the stock-equilibrium conditions that bind them together. The monetary approach, on the other hand, tends to neglect the particular configuration of the current and capital

79. J. H. Williamson, "On the Normative Theory of Balance-of-Payments Adjustment," in G. Clayton and others, eds., Monetary Theory and Monetary Policy in the 1970s, Proceedings of the 1970 Sheffield Money Seminar (London: Oxford University Press, 1971), pp. 235-56. The problem of a nonoptimal composition of the balance of payments is also noted in Alexander K. Swoboda, "Monetary Policy under Fixed Exchange Rates: Effectiveness, the Speed of Adjustment, and Proper Use," Economica, n.s., vol. 40 (May 1973), pp. 136-54. 
accounts associated with the period of transition to stationary-state equilibrium, and thus to overlook the economic effects of different levels of indebtedness, which are the stock counterpart of different payment configurations, not only on the adjustment path, but also on the long-run equilibrium itself in anything other than the stationary state.

Indeed, once one acknowledges that the nature of the adjustment path may itself influence the level at which long-run equilibrium is ultimately achieved, it becomes clear that the concentration of the monetary approach on monetary aggregates and the general price level obscures some important questions. In particular, by generally assuming a one-to-one relationship between wages and prices, it tends to ignore the importance of short-run changes in this relationship (which are likely in the wake of a devaluation, for example), not only for the distribution of income, but also for the level of employment, the rate of investment, and the rate of economic growth. ${ }^{80}$

The various questions raised so far apply, although in differing degrees, not only to global monetarism but to the monetary approach as well. Most of the heterodox policy implications cited at the beginning of this paper, however, are derived from the full set of global-monetarist assumptions, including the tendency to regard the conditions of stationary-state equilibrium as relevant for policy analysis. The monetary approach, taken alone, raises important questions about the efficacy of exchange-rate policy -or, at least, focuses on some constraints under which it operates-that were frequently ignored in Keynesian analysis. In particular, it makes clear that countries cannot persistently inflate at different rates without eventually forcing a change in the rate of exchange between their currencies, and that these changes, in turn, feed back onto the domestic price level in ways that are not fully reflected in either elasticities or multiplier analysis. But global monetarism denies the utility not only of national exchange-rate policies, but also of any form of macroeconomic stabilization policy, both because the level of real income is assumed to be exogenous and because the requirements of stock equilibrium deprive exogenous disturbances of anything beyond transitional effects on real economic variables. Yet, in the

80. For a monetary-approach model that allows the wage-price relationship to vary, see Dornbusch, "Real and Monetary Aspects," cited in note 42. Changes in this relationship are explicitly excluded by the assumptions of global monetarism, among which are the absence of money illusion and the neutrality of money vis-à-vis real variables. 
real world, economies do in fact remain for considerable periods in disequilibrium-in particular, with persistent unemployment-and both exogenous disturbances and stabilization policies have nontrivial effects. In a world where the stabilization of income and employment at high levels (or along a reasonable growth path) is a primary concern of policymakers, an analytical model that eliminates these concerns by assumption operates under a certain handicap.

The macroeconomic assumptions of global monetarism appear to rest, explicitly or implicitly, on the microeconomic foundations provided by the classical "pure," or barter, model of international specialization and exchange. One of the critical assumptions of this model is that reallocations of production along the aggregate production-possibilities curve take place without friction or cost. Yet, in fact, the reallocation of factors of production from one use to another imposes real costs; in particular, the real income lost as a result of the unemployment associated with the reallocation process, whether or not it is subsumed under the rubric of frictional unemployment, represents a permanent loss to the society. Thus, a valid aim of government policies is to minimize the losses associated with reallocation; or, more accurately, to maximize the benefits net of the losses associated with it.

The recognition of adjustment costs, and their minimization, as a legitimate target of economic policy, also suggests that the optimal adjustment process may vary according to the disturbance that gives rise to it. ${ }^{81}$ In particular, the changes in relative prices and associated factor reallocations that characterize the classical adjustment mechanism (under both fixed and flexible rates) may be essential to restore equilibrium in the face of a trend disturbance or one that takes the form of a one-time permanent shift. Such

81. The question of the optimum speed of adjustment is also relevant, although the criteria are not well defined. Okun is concerned that the automatic price-adjustment mechanism (for example, under fixed rates) may be too slow: "According to the St. Louis model, price flexibility works very slowly to restore equilibrium, with a process of adjustment that lasts for many years" ("Fiscal-Monetary Activism," p. 150). While Gray also worries sometimes about the slowness of this adjustment process (Aggregate Theory, p. 4), at other points in his argument (ibid., chap. 5), he is concerned that the market adjustment mechanism may sometimes work too quickly (for example, under flexible rates). Friedman argues that "there seems no reason to expect the timing or pace of adjustment under the assumed conditions [freely flexible rates] to be systematically biased in one direction or the other from the optimum . . ." ("Case for Flexible Exchange Rates," p. 434). 
responses may entail unnecessary adjustment costs, however, in the case of self-reversing disturbances. ${ }^{82}$ The postwar history of the "fundamental disequilibrium" criterion for exchange-rate change incorporated in the Articles of Agreement of the International Monetary Fund makes clear how difficult it is to distinguish ex ante among the classes of disturbance, and warns how great is the temptation to diagnose a disturbance as self-reversing in order to avoid the social and political pain of even necessary reallocations. But the search for a least-cost adjustment mechanism remains valid, and the distinctions among disturbances just outlined imply that the "quasi-adjustments" (or financing of imbalances) that governments frequently resort to as alternatives to the classical adjustment mechanism and its associated reallocations may indeed be, in the case of selfreversing disturbances (such as certain shifts in asset preferences), the least costly and therefore the most appropriate response. Global monetarism, which views all disturbances and all responses through their impact on the demand for and supply of money, inevitably ignores such distinctions, to which the traditional piecemeal Keynesian approach to balance-of-payments analysis and its policy implications has tended to be more (sometimes excessively) sensitive. More generally, global monetarism, with its emphasis on the automaticity of the adjustment process and its suppression of structural characteristics, is ill suited to the incorporation of divergences between private and social optima. In contrast, the traditional Keynesian framework views the achievement of equilibrium-both internal and external-as a specific objective of deliberate government policy, rather than as the automatic result of the operation of market forces. ${ }^{83}$

Finally, there is the question of whether the nation-state or the world is the best primary focus of analysis. The monetary approach has rightly called attention to certain long-run tendencies toward international integration which were not reflected in the Keynesian analyses of the fifties and sixties. Global monetarism goes much further, essentially denying any relevance to national boundaries. In other words, its assumption of perfect substitutability and perfect arbitrage across national boundaries in both commodity and asset markets essentially erases the distinction between "domestic" and "foreign" and implies that only the world (rather than the

82. Gray, Aggregate Theory, chap. 5.

83. Whitman, Policies for Internal and External Balance, p. 2. 
national) values of variables and parameters are relevant to behavioral relationships. $^{84}$

As Cooper has noted, the efficiency implications of pure trade theory argue that, for private transactions, the artificial boundaries of the nationstate should have no significance; for private markets in both goods and factors of production, the optimum currency area is the world. The economic justification for nation-states, then, lies in the existence of public or collective goods and of differences in the consumption preferences for such goods among the citizens of different nations. ${ }^{85}$ The greater the divergences among countries with respect to the transformation curve or the indifference map for public goods, the greater will be the welfare costs of international economic integration in the sphere of such goods that must be set off against the efficiency gains from integration of private markets. ${ }^{86}$

Indeed, one can read in the recent history of international economic relationships a growing tension between the rapid increase-and acknowledged benefits-of international market integration in the private sphere and the almost total absence of integration or even coordination of public policy across national boundaries, which reflects at least in part a recognition of the welfare costs of such integration where collective goods are concerned. It seems logical, then, that the global-monetarist approach, with its stress on the inherent efficiency and stability of the private sector and its view of government intervention as a source of exogenous shocks, should emphasize the openness of national economies and the importance of adjustment mechanisms dependent on market integration, and should rest its preference for fixed over flexible exchange rates on the benefits of market integration in the private sector. The Keynesian approach, on the other hand, sees government as a stabilizer of fluctuations in the private sector, equilibrium as a state to be achieved by deliberate policy intervention rather than

84. Meltzer argues that in such models "an essential difference between the multicurrency world that emerged under the Bretton Woods Agreement and the gold standard is overlooked or neglected." See "Monetary Approach to Inflation and the Balance of Payments."

85. Richard N. Cooper, "Worldwide vs. Regional Integration: Is There an Optimal Size of the Integrated Area?" (paper presented at the Fourth World Congress of the International Economic Association, Budapest, 1974; processed).

86. For an example, in terms of the tradeoff between inflation and unemployment, see Marina v. N. Whitman, "Place Prosperity and People Prosperity: The Delineation of Optimum Policy Areas," in Mark Perlman and others, eds., Spatial, Regional and Population Economics (Gordon and Breach, 1972), pp. 359-93. 
through the operation of automatic market forces alone, and collective goods as an important component of the social-welfare function. Those who take this view tend to base their concern with explicit balance-of-payments policies in a fixed-rate world and their frequent preference for managed flexibility on the need to insulate the domestic economy from foreign disturbances and to permit national governments to pursue independent macro stabilization policies, in a world of integrated markets. Fundamentally, this view regards exchange-rate policy as one instrument by which governments may preserve some independence in the policy sphere with a minimum of disruption to the benefits of market integration in the private sphere. But full-fledged global monetarism, which tends to regard conventional stabilization policies as both unnecessary and ineffective, is plagued by no such tradeoff and is free to focus on a single criterion for the exchange-rate regime: one that will maximize the efficiency benefits of worldwide integration of commodity and factor markets.

\section{Theoretical Progress and Policy Relevance: A Scorecard}

Without doubt, the challenges to postwar orthodoxy surveyed in this paper, and the responses of the modern Keynesians stimulated by them, have engendered rapid progress in the area of theoretical specification and model building. The explicit recognition of the interactions among all markets in a general-equilibrium system; the specification of full equilibrium in the market for money (and other financial assets) in stock as well as flow terms; the recognition that the response of an economy to a devaluation is properly analyzed in a macroeconomic rather than a microeconomic context; and the distinction among impact effects, the dynamic adjustment process, and long-run stationary-state effects of a disturbance-these are only some of the theoretical clarifications and refinements that have emerged from a dynamic process of challenge, response, and synthesis over the past decade.

In terms of policy relevance, it is the monetary approach to the balance of payments-rather than the entire package here termed global monetarism-that has yielded fruitful insights. Its assertion that, under pegged exchange rates, the national money supply should be regarded as an endogenous rather than a policy variable appears to hold almost fully for a few countries in the short-to-medium run, partially for at least a number 
of others, and not at all for the United States, the major supplier of international reserves in recent years. Even so, the monetary approach has yielded useful implications for the impact of domestic monetary policy in the United States on its own balance of payments, on the internal economies of other countries, and on the viability of the gold-exchange standard that characterized the Bretton Woods system.

Similarly, the flexible-rate analogue of the monetary approach - the asset approach to exchange-rate analysis-has proved extremely valuable for understanding and interpreting the experiences of recent years. It has focused attention on such factors as relative money-market conditions and shifts in portfolio preferences as important determinants of exchange rates in the short and medium run, as opposed to the exclusive focus on purchasing-power-parity conditions and the longer-run structural phenomena usual in Keynesian analysis. This asset-market approach provides a useful framework for consideration of possible problems created by short-run "overshooting" of longer-run equilibria, such as price "ratchets," bankruptcy thresholds created by capital-market imperfections, and related issues.

Most of the more revolutionary policy implications emerge, however, not from the monetary approach or its flexible-rate analogue, but from the full package of global-monetarist assumptions. And these, by and large, miss the boat for applicability to current problems. In their assumption of perfect substitutability between domestic and foreign goods and financial assets, and of perfect arbitrage across national boundaries in both commodity and capital markets, for example, the global monetarists go too far in correcting an error implicit in much of the earlier Keynesian analysis. Market integration across national boundaries has certainly increased in recent years but, quite apart from the remaining barriers to trade, considerable evidence suggests that, at least for certain classes of commodities and financial assets, domestic and foreign counterparts are not regarded as perfect substitutes, creating substantial deviations from the "law of one price," at least in the short run. More broadly, while the global monetarists perform a service in insisting that the international repercussions of domestic policies must be recognized as more than second-order qualifications to a closed-economy analysis, they tend to dismiss too lightly the fact that the nation-state remains the basic economic entity in the modern world and that policy independence remains an important concern of national governments. 
Finally, and most important, by focusing on the long-run general-equilibrium characteristics of the economic system-in particular, by assuming that real output is determined exogenously and that money is neutral vis-àvis real variables-global monetarism consigns to irrelevance the problems of economic stabilization with which most policymakers are primarily concerned and to ineffectiveness the traditional macroeconomic tools of monetary and fiscal policy. In another context, Okun once concluded that the monetarists "have provided good questions and bad answers." 87 As I see it, the global monetarists have raised some good questions but have buried some even more important ones. Specifically, they insist, correctly, on the importance of recognizing the long-run implications of policies undertaken to achieve short- or medium-term goals, but they are wont, wrongly, to ignore short- and medium-term effects in focusing on the long-term fullequilibrium situation. The questions they thus skip over are important not only because of the short time horizon of policymakers, but also because of differences in social costs associated with different adjustment processes and varying lengths of the transition period. They are important, even more fundamentally, because in the real world, long-run equilibrium is a state perhaps approached but never reached, and, in a dynamic rather than a stationary economy, the characteristics of the adjustment path, while the economy is out of equilibrium, are bound to affect the characteristics of the long-run equilibrium itself.

As with most challenges to orthodoxy, a winnowing process is now under way, and the most fruitful component of that challenge-the insights of the monetary approach to payments analysis-is rapidly being co-opted into the conventional wisdom itself. Beyond that, global monetarism offers little of policy relevance at this time, and the practical problem remains: "how to marry the monetarist and the Keynesian analysis in a way relevant to the short-run context (albeit a run of several calendar years) with which the policy-makers are concerned, and which is characterized both by variations in production and employment as well as in money prices, and by variations in the relations among export, import and non-traded goods prices which are assumed away in the long-run equilibrium analysis of the monetarist approach." 88

87. "Fiscal-Monetary Activism," p. 157.

88. Johnson, Further Essays in Monetary Economics, p. 14. 


\section{Comments and Discussion}

William H. Branson: Marina Whitman's paper surveys recent developments in the monetary and monetarist approaches to analysis of the balance of payments. The survey is interesting and evenhanded, but as is appropriate for a survey, it offers no new results. Therefore, I have nothing to attack ruthlessly (which would be no fun anyway), and I can offer only differences of approach, emphasis, and interpretation. Whitman's paper begins with global monetarism, and then goes on to discuss other approaches (monetary, Keynesian, elasticities, absorption, any combination of the above) to understanding the balance of payments as extensions of global monetarism. My approach is to treat a generalized IS-LM model of short-run equilibrium with several assets as the general case, and then to look at the monetary approach and global monetarism as increasingly special cases of this model. I think this improves understanding, and puts the various approaches in proper perspective. (I am encouraged to wander in the no-man's-land between the "monetarist" and "Keynesian" international schools since I am viewed by some of my professional colleagues as a "die-hard Keynesian" and by others as a "closet monetarist.")

Before getting into a brief discussion of the relationship of the monetary approach and global monetarism to the standard post-Keynesian analysis of the balance of payments, I should point out one aspect of the Whitman paper that I would fault. Toward the end of the paper, Whitman seems to criticize the monetary approach for having nothing to say about the composition of the balance of payments. While this observation is true, the monetary approach makes no claim to addressing this matter, so I think that this criticism is misplaced.

Whitman focuses on global monetarism and treats the more general monetary approach to analysis of the balance of payments as an extension 
of monetarism. She then goes on to relate the monetary approach to the traditional Keynesian elasticities-absorption literature as further extensions. I think that understanding of the roles of the monetary and monetarist approaches would be aided by reversing the order of this discussion, treating the monetary approach as a special case of the traditional postKeynesian macro framework, and global monetarism as a polar case of the monetary approach. This ordering places global monetarism in proper perspective; Whitman's paper contains many references to scholarly work (published in the journals, rather than in the popular press) on the monetary approach, and few on global monetarism.

Beginning with the standard IS-LM model of income determination, I want to introduce, in the interest rate-income space, a third line that is the locus of points where the balance of payments is zero. Call this the BP line; it is positively sloped. If the IS-LM equilibrium intersection is above the $\mathrm{BP}$ line, the economy is experiencing a balance-of-payments surplus; below the BP line, a deficit (all of this assuming fixed exchange rates). A change in the exchange rate shifts both the BP and IS curves in this picture, and the elasticity story is about the direction and extent of these shifts, while the absorption story is about the economy's reactions to them.

The monetary approach simply adds to this story the observation that if the effects of a nonzero balance of payments on the money supply are not sterilized, the momentary IS-LM equilibrium point cannot be a full equilibrium, since the money supply is changing. In the absence of sterilization, a necessary (but not sufficient) condition for full stock equilibrium would be an IS-LM intersection on the BP line, so that the money stock is constant while the money market is in equilibrium. It is worth noting that the role of the balance of payments in changing the money stock in open-economy macroeconomics is almost exactly analogous to the role of the "government-budget constraint" in a closed economy. The Blinder-Solow results in the closed economy (cited by Whitman) are exactly the same as Mundell's famous results with fixed exchange rates. ${ }^{1}$

The key assumption in the monetary approach, which could be a testable hypothesis, is that monetary authorities do not or cannot sterilize (or nul-

1. See Robert A. Mundell, "Capital Mobility and Stabilization Policy under Fixed and Flexible Exchange Rates," in Richard E. Caves and Harry G. Johnson, eds., Readings in International Economics (Irwin, 1968). For the comparison, see also William H. Branson, "Flow and Stock Equilibrium in a Traditional Macro Model," Working Paper G-74-02 (Princeton University, International Finance Section, May 1974). 
lify, in Whitman's term) the balance-of-payments surplus over any significant period. This assumption makes the full stock-equilibrium position the interesting one for the monetary-approach analyst, and his comparisons are usually made between such equilibria. The evidence on whether sterilization is possible is mixed. According to the findings cited by Whitman, some significant persistent sterilization is possible.

The principal inference usually drawn from the monetary approach is that between stock equilibria, changes in exchange rates alter the reserve level by inducing temporary payments imbalances, but that in equilibrium, the balance is zero. In the monetary approach, exchange-rate policy is reserve policy, not balance-of-payments policy. However, the monetary approach also implies that changes in exchange rates can be effective in eliminating balance-of-payments disequilibria caused by shifts in other variables-a point that is underemphasized in the Whitman paper (and played down by most monetary-approach writers). If the balance of payments is not in equilibrium to begin with, changing the exchange rate could be more effective than waiting for the effects of the disequilibrium on the money stock to work their way through the system. This should be the relevant inference drawn from the monetary approach; after all, changes in exchange rates under the Bretton Woods system were responses to disequilibrium situations.

Global monetarism narrows the monetary approach even further by adding "small country" assumptions-as international economists call them-and wage flexibility to the nonsterilization assumption. According to the small-country assumptions, the economy is a price taker facing a world interest rate and price level, and can buy or sell all it chooses at those prices. These assumptions fix the price level and the interest rate. The assumption of flexible wages fixes output and employment at the full-employment level. With all the determinants of the demand for money fixed, any change in the domestic base has to be offset by a one-for-one change in foreign reserves. In the polar case of global monetarism, the world money stock drives the price level and national monetary policies merely allocate reserves.

The evidence cited above overwhelmingly confirms that movements in foreign-exchange reserves do not offset on a one-for-one basis changes in the domestic base (or vice versa), and it is clear that most countries experience fluctuations in price levels and interest rates relative to world averages, as well as an occasional deviation from full employment. Thus, the polar 
case of global monetarism may describe some long-run average, but it seems hardly relevant for economic policy.

Whitman discusses asset-market determination of the exchange rate, in the short run, as the flexible-rate dual to the monetary approach with fixed rates. Here the exchange rate is viewed as the relative price of national moneys, and as adjusting in the short run so that the existing stocks are willingly held. In the monetary approach, with fixed rates the balance between demand for and supply of money determines the official-settlements balance; with flexible rates it determines the exchange rate. In both cases, the basic equilibrium condition is an asset- or stock-market equilibrium.

In the short run, the exchange rate is determined, along with interest rates, in the asset-equilibrium LM sector. This is a straightforward extension to the open economy of Tobin's general-equilibrium approach to monetary theory. In a simple case with two countries, each with an imperfectly substitutable bond and a money, asset-market equilibrium conditions determine values for two interest rates and the exchange rate. ${ }^{2}$ An immediate implication is that, in the short run, exchange rates should exhibit the variability of stock-market prices. This is an insight of the assetmarket approach that was missed by most early advocates of flexible exchange rates.

In the asset-market approach with flexible rates, the exchange rate is determined in the short run by requirements of asset-market equilibrium. The exchange rate then influences the current account with a lag. Since rates are flexible, the capital-account balance is the negative of the current account, so the current-account balance also is the rate of change of net foreign-asset holdings. Thus, the current-account balance feeds holdings of net foreign assets, moving the exchange rate. The system works as follows:

$$
\underset{\substack{\text { Asset } \\
\text { stocks }}}{\uparrow} \rightarrow\left(\begin{array}{l}
r \\
e
\end{array}\right) \rightarrow \underset{\text { account }}{\text { Current }}=-\begin{gathered}
\text { Capital } \\
\text { account }
\end{gathered}
$$

Here $r$ is the vector of interest rates and $e$ is the vector of exchange rates. This system comes into full equilibrium (stationary or growing) when all stocks reach equilibrium values. The important aspect of the current account here is its role as the foreign net-worth account; it gives the rate of

2. For the analysis, see Lance Girton and Dale W. Henderson, "Central Bank Operations in Foreign and Domestic Assets under Fixed and Flexible Exchange Rates" (Board of Governors of the Federal Reserve System, August 26, 1974; processed). 
net foreign investment. ${ }^{3}$ The consistency of this mechanism with long-run purchasing-power parity (PPP), can be illustrated as follows. If from an initial equilibrium, the home government starts running a budget deficit, increasing the rate of growth of supply of home-denominated assets (money or debt), the exchange rate rises. This stimulates net exports and aggregate demand, pulling up the price level. Eventually, the price increase brings the system back to PPP with a higher exchange rate. The analogy to the Tobin view of the relationship between equity prices and investment should be obvious.

The twist that the monetary-approach analysts such as Kouri and Mussa apply to this asset-equilibrium approach is to drop the securities market, or capital account, from the story. This is done either by making smallcountry assumptions that fix home interest rates, or by using a two-asset model so that the bond market can be dropped. The balance of payments then becomes a matter of exchange of money for goods, in which the exchange rate is determined only by the relative stocks (levels or growth rates) of money. In this special case, the asset-market view of exchange-rate determination collapses to simple consideration of relative money stocks, and money takes on a unique role among assets.

By discussing models without bonds as the initial case, Whitman's paper leaves the impression that the monetary approach and the asset-market approach are the same thing, except for technical details. In fact, the monetary approach is a special case of the asset-market approach, and the gap between the two is as wide as the theoretical distance from Yale to Chicago. The essential simultaneity of interest-rate and exchange-rate determination is clear in the Dornbusch paper on flexible exchange rates cited by Whitman (note 51).

In the flexible-rate case, the current-account balance is the rate of accumulation of net foreign assets by the private sector, and is part of the saving decision. This interpretation is clear in the asset-market view of exchange-rate determination. With fixed rates, the current-account balance is the national rate of accumulation of net foreign assets, with the intervention policy of the central bank determining the public-private split. Controlled floating probably should be modeled in this manner.

The important insight here is that the natural separation in the balance-

3. Charles P. Kindleberger emphasizes this role of the current-account balance in "Measuring Equilibrium in the Balance of Payments," Journal of Political Economy, vol. 77 (November/December 1969), pp. 873-91. 
of-payments accounts is between the flow account-the current accountand the two stock accounts-the capital account and the official-settlements balance. The last two are in the LM or asset sector of a properly specified model of an open economy, and the first is in the IS or flow sector. The interaction over time is that the flows are the rates of change of the stocks. Thus, among all the balances, only the current-account balance (give or take unilateral transfers and SDR allocations) has an unambiguous interpretation: it is the rate of accumulation of net foreign assets.

The monetary approach makes the official-settlements balance the center of analysis only by lumping together the capital account and current account, or by ignoring the capital account. In doing so, it assumes a uniqueness of money in the spectrum of assets that is convenient for pedagogy and illuminating for analysis, but probably not realistic. (Since private accumulation of foreign money is a capital-account term, the official-settlements balance cannot technically summarize money transactions.) Correct integration of the external accounts into models of domestic economies probably requires separation of the current account, rather than the money account, from the rest.

David I. Fand: Marina Whitman's paper provides a comprehensive view of the monetary approach to the balance of payments. She faces a very difficult problem because so many writers are developing this approach and the literature is expanding very rapidly. She has worked conscientiously and, on the whole, successfully to present the main ideas.

Identifying the main currents in any approach poses difficult questions of selection and judgment. Whitman views the content of global monetarism, as she defines it in this paper, as part of the mainstream of the monetary approach. Yet, two examples suggest that it may be one particular adaptation of the monetary approach and that it may lie outside the mainstream. First, most of the writers favoring the monetary approach also favor flexible exchange rates. This advocacy is hard to square with global monetarism as defined by Whitman. Second, the law of one price, as enunciated by the global monetarists, implies that somehow the price of haircuts in India will be equated to the price of haircuts in the United States. On the other hand, many writers who follow the monetary approach limit the law of one price to traded goods so that it influences payments imbalances or exchange rates, or both.

As Whitman suggests, it is useful in surveying this literature to distin- 
guish between the soft version and the hard version (to borrow terms introduced by Robert Solow). The soft version, as I see it, advances propositions that most people would accept. This version of the monetary approach (following Dornbusch's recent discussion in the American Economic Review, vol. 65, May 1975, pp. 147-48) first emphasizes that the balance of payments and the balance of trade basically involve questions of macroeconomics and monetary-fiscal policy. Any approach that does not put the problem in a macroeconomic setting is incomplete, if not misleading. While all would accept this view, in some discussions it tends to be overlooked.

A viewing of the balance of payments in a macroeconomic setting casts doubt on the validity of the $\mathrm{J}$ curve-the idea that devaluation worsens the trade balance in the short run. No macroeconomic relation would predict an increase in spending relative to income as a result of a change in exchange rates independently of monetary and fiscal policy.

Another issue is the alleged permanent relative price advantage for exports following a devaluation. The assumption that a change in exchange rates exerts permanent real effects implies some kind of money illusion. Under some monetary and fiscal policies, it will have long-run real effects, but then it is the monetary-fiscal setting and the change between income and expenditure that are essential. The exchange rate is only a helpful way of altering the relative prices of domestic goods and traded goods.

A change in exchange rates accompanied by a validating macroeconomic policy will have effects on the competitive position of a country in world markets. These effects arise not because exports become cheaper and imports more expensive, but rather because the relation between domestic and traded goods is altered. The improvement for the domestic producers of traded goods derives from the lower real costs in their sector.

The enhanced competitive position of the home country extends beyond the established traded goods. The reduced domestic absorption causes some goods to move from the domestic-goods sector to the traded-goods sector, as the decline in their relative prices makes them competitive even given tariffs and transportation costs.

The monetary approach to the balance of payments does not require a small-country assumption, nor does it assume any particular or unusual relations for the prices of internally traded goods. What it does assume is that the prices for identical traded goods, with allowance for tariffs, transportation costs, and so on, are equalized between countries. Otherwise, there would be profit opportunities to be eliminated by arbitrage. 
Exchange rates are determined in the market for assets and not in the market for flows of foreign exchange. This concept is far removed from the view of the exchange rate as a means of balancing a current account with an independently specified capital account. It also lends substantial scope for expectations in the determination of the exchange rate. The erratic movements in exchange rates in the last two years are not all that surprising, considering the kinds of stock adjustments that were involved.

In general, in the soft version, anything that affects the demand for or supply of money will, as a first approximation, be reflected by changes in the exchange rate. Finally, the attractiveness of flexible rates for monetary policy may not be as great as previously believed. Flexible rates allow a country to choose its own rate of inflation, but they do not insulate a country against real disturbances originating abroad.

A hard version of the monetary approach to the balance of payments first emphasizes that all payments imbalances and disequilibria are monetary in essence. Structural deficits or surpluses do not exist, unless one includes in the concept of structure a propensity to rely on inflationary financing. Any assertion that real changes cause payments deficits or surpluses is correct only if the real change is assumed to result in policies that run down international reserves as an alternative to reducing real absorption or borrowing on commercial terms. ${ }^{4}$

Disequilibria in the balance of payments must be transitory, and their duration will be relatively short, unless they are continually renewed by noncommercial transfers of money. A country may support a deficit by replacing international reserves with domestic credit, but it will eventually run out of reserves. Similarly, a country may be able to "sterilize" its acquisition of international reserves, but eventually it will exhaust its stock of domestic credit assets. It can continue to sterilize reserve inflows only by lending the money back to foreign countries in noncommercial ways.

All payments disequilibria can be handled by the use of domestic monetary policy without resorting to changes in exchange rates. We should exclude a disaster like the 1930s, when all currencies were overvalued in terms of the international reserve asset; in this case the solution should have been an all-around increase in the domestic prices of the reserve asset without any change in the relative values of national currencies.

4. See Harry G. Johnson, "The Monetary Approach to Balance of Payments Theory and Policy: Methodological Explanation and Policy Implications," forthcoming. 
Devaluation is a substitute for domestic credit contraction, operating to reduce the world value of the country's money supply; and appreciation is a substitute for domestic credit expansion, operating to increase the world value of a country's money supply. The argument for either devaluation or appreciation rests on its use as a means of avoiding the equivalent contraction or expansion in the domestic money supply, and thus on price and wage rigidity or money illusion. A change in exchange rates can be rendered ineffective by an inappropriate, counteracting, monetary policy. Also, a devaluation (revaluation) will have to be repeated, unless it is accompanied by a slower (faster) rate of domestic credit expansion.

Import quotas, tariffs, exchange controls, and other restrictions on trade and payments will improve the balance of payments if they induce an increase in the demand for money. Like those of a devaluation, any such effects will be purely transitory, lasting only until the supply of money is increased through payments surpluses to meet the larger demand. But if the controls are accompanied by domestic credit expansion, designed to facilitate adjustment to the restrictions and the accompanying rise in prices, the balance of payments will not be improved and may be worsened.

A faster rate of economic growth will tend to improve a country's balance of payments by increasing the demand for money. This potential improvement will be realized only if the accelerated economic growth is not accompanied by accelerated expansion of domestic credit.

In brief summary, what is the connection, if any, among global monetarism, the monetary approach, and monetarism? The hard version of the monetary approach emphasizes the stability in the demand for money and attributes many of the disturbances to government activity, especially with respect to the variations in the supply of money. Moreover, the view that payments disturbances emanate from the monetary side, and not from the trade or capital side, is consistent with the view that the private sector is stable relative to the government. The hard version of the monetary approach does share some of the assumptions of monetarism, in contrast to the soft version, which takes a more eclectic view. As already noted, the global monetarists, who favor fixed rates, differ from most other writers who follow the monetary approach. Finally, the global monetarists who view the nominal money stock as determined by the balance of payments, and thus beyond the reach of the monetary authorities, clearly differ from the monetarists. 
Lawrence B. Krause: Marina Whitman offers us a classic paper, much as Anne Krueger's paper was classic, in focusing attention on very important developments in theory. The paper does help clarify the issues.

I shall concentrate on the area of my own comparative advantage, which lies in evaluating the usefulness of theory for policy analysis. To do so, I shall look more closely at global monetarism than at the monetary approach. The global monetarist has a clear policy prescription: fix the exchange rate and rely on automatic stabilizers for balance-of-payments adjustments. In general, Whitman has bent over backwards to give credit, not only to the monetary approach, but also to the global monetarists, and I think she occasionally lost her equilibrium in the bending. She properly distinguishes between the two. But I think one cannot really give credit to either for recognizing the balance of payments as a monetary phenomenon, unless Fritz Machlup, who has always written in that vein, is designated as a monetarist pioneer.

It is true that the older Keynesian tradition of balance-of-payments analysis with its elasticity approach, working from the top down rather than the bottom up, often ran out of steam when it got to short-term capital movements. Indeed, that criticism of the projections of the U.S. balance of payments made by Salant and his associates a decade ago was offered at the time by Harry Johnson and was the most valid criticism of that study. The trouble with the earlier approach is that it offered no way to integrate money markets, security markets, and goods markets-not a critical oversight in the case of real disturbances, but a serious weakness if the disturbances of the system are on the monetary side, as they have often turned out to be.

When I inspect the substance of global monetarism as an alternative approach, I find it totally an analysis of fixed exchange rates, and I think Whitman's exposition should make that clearer. When it is applied to a system of flexible exchange rates and to the way an exchange rate is determined, global monetarism tells me merely that the price of a currency is affected by supply and demand. I cannot give it much credit for that, because I learned that a long time ago. Perhaps it helps a little by telling me to look at assets properly as part of demand and supply.

Whether one learns something by going through the asset approach depends on the realism of the assumptions. Let me focus particularly on that regarding sterilization by central banks. I am amused to note that Robert Mundell in 1961 stressed that central banks sterilized inflows so regularly 
that they had turned the automatic adjustment mechanism into an anachronism. He even called the article "The International Disequilibrium System." ${ }^{5}$

The system may have changed some since 1961, but not all that much. The truth is that central banks sterilize to some extent and they don't sterilize to some extent. For instance, in 1971, when Japan had a gigantic inflow of foreign reserves, everybody said they had lost control of their money supply. More recent analyses of that experience show that that was not true at all. The Japanese, in fact, sterilized a major share of that inflow; that they didn't do so during a subsequent episode can only mean that they did not want to. In other words, they were not the pawns of the inflow of foreign money: they were following the monetary policy that they wanted.

The assumption furthest from reality is that the short run can be ignored. The concentration on the long run assumes away all of the problems that make the balance of payments a problem. It is about the short run and the dynamics of the adjustment process that most governments worry most of the time. In that context, I would like to nominate one sentence in this paper for the understatement of the month: "In a world where the stabilization of income and employment at high levels (or along a reasonable growth path) is a primary concern of policymakers, an analytical model that eliminates these concerns by assumption operates under a certain handicap."

On the question of goods arbitrage, even when the assumption is limited to traded goods, it is still really not correct and may not pick up some essential aspects of behavior. In considering the prices of consumption goods that are traded, the price of meat, for example, relative to other goods is shockingly different in Australia, the United States, and Japan. Yet meat clearly is a traded good, and the behavior of its prices raises questions about the general usefulness of the law of one price as an assumption even for traded goods.

I am particularly concerned about the monetary approach because it may distract attention from important issues. Let me illustrate: I recently heard a paper presented on the Mexican balance of payments. The work was done in a global-monetarist framework and empirically verified that approach. Of course, Mexico is a small country with the United States next to it, a fixed exchange rate, and a monetary base that reflects its reserves. But why does the balance of payments matter to Mexico? Is their debt to

5. Kyklos, vol. 14 (fasc. 2, 1961), pp. 153-72 (adaptation appears in Robert A. Mundell, International Economics (Macmillan, 1968). 
the world rising or are they becoming a creditor? Are the short-run and the long-run capital flows sustainable within the Mexican position? The theory may "work" and still be destructive because it buries these issues.

My own preference is for an eclectic approach that begins with absorption, but that allows other things to be added, depending on the sources of the disequilibrium. Let me say finally that I object to economic theories that depart from the reality of political economy. Nationalism cannot be ignored, particularly when it is on the rise, as I think it is. Leaving out the hegemonic power that has always existed under systems of fixed exchange rates constitutes blindness to the reality of political economy.

Walter S. Salant: I am in general agreement with the conclusions of Marina Whitman's paper and strongly endorse most of them. But I have problems with some points she makes on the way to her conclusions.

To avoid any possible confusion, let me make clear at the outset that I understand the paper to use the term "global monetarism" to refer only to the view that all real variables are determined by real supply and demand functions, that monetary matters are separate and don't affect those real demand and supply functions, and hence that changes in exchange rates from one fixed rate to another affect only the price level and not the net current-account balance, expressed in foreign currency. That is a short description of an extreme view held by a small subset of the large set of those who approach balance-of-payments problems from a monetary point of view; it includes Robert Mundell and Arthur Laffer and, so far as I know, few, if any, others.

Whitman displays a generosity toward that extreme position that seems to me excessive. Her generosity is reinforced by her acceptance of a few theoretical points that I consider incorrect and by her crediting that view with valid points that are common to all approaches. On policy matters, I think she comes out with a properly negative conclusion, but her tone is kinder than the view deserves.

As to theoretical points, my first comment concerns international price arbitrage, or the so-called law of one price. That law says that prices of perfectly competitive, internationally traded commodities cannot differ in different national markets by more than the cost of transport and the level of tariff barriers in the importing country (or the equivalent, for nontariff barriers). This rudimentary proposition in the theory of international trade has long been recognized by all economists. Whitman does take account of 
this and quite correctly attributes to global monetarists only an extension of it to price levels. I might note that the law of one price must apply, in fact, to all undifferentiated commodities, whether traded or not; prices of nontraded goods also cannot differ by more than the costs imposed by these transport and trade barriers and are not traded because these costs are too high. But under reasonable realistic assumptions, changes in exchange rates shift goods between traded and nontraded categories. For all commodities there is an export point and an import point, analogous to the old gold points; hence, commodities may shift from being imported to being not traded to being exported and vice versa, even when the law of one price prevails. (All of this was pointed out by Frank Graham in the American Economic Review in 1925.6) That makes awkward an analysis that is cast in terms of a world in which output is rigidly separated into traded and nontraded categories.

Moreover, even if all markets were perfectly competitive so that the law of one price held for all products, a change in exchange rates could affect trade balances. A change in the relative price of the same commodity in two or more national markets is not necessary to obtain that effect. As I pointed out when this same issue came up in the discussion of William Branson's paper for BPEA, 1:1972, the relationship of the foreign to the domestic price does not have to change to induce substitutions of production, for such substitutions result not only from differences in prices in the two markets but from changes in the relationship of price to cost within an individual country. For example, when a country that exports small amounts of wheat devalues, the price of its wheat in foreign currencies is unchanged, but its wheat production becomes more profitable relative to its production of nontraded commodities, and more is exported. To avoid such effects on trade, it would be necessary for changes in exchange rates to leave unaltered not only the relation between product prices among countries but the relation among factor prices both among countries and within them. Such invariance cannot be deduced from international arbitrage alone for any period with which exchange-rate policy is concerned.

Thus, the law of one price arising from commodity arbitrage does not rule out effects of devaluation on trade. On this point, Whitman cites Jacob Frenkel as saying that the law is irrelevant to the refutation of the simplified Keynesian conclusions, but she does not seem to support his position.

6. Frank D. Graham, "Germany's Capacity to Pay and the Reparation Plan," American Economic Review, vol. 15 (June 1925), pp. 209-27. 
I think she should. Only in an imperfectly competitive world market in which the demand for a country's exports is not infinitely elastic does an increase in exports require a cut in the price measured in foreign currency.

In short, the assumptions about price arbitrage and changes in terms of trade, besides not being unique to the monetarists, are not necessary for their conclusions or for refutation of the conclusions of others.

On a second point of theory, I think the paper is excessively generous to global monetarism-and, indeed, to the monetary approach-in crediting them with the recognition that the partial-equilibrium assumptions underlying the elasticities approach are not adequate to deal with the analysis of changes in exchange rates. That has been recognized at least since Sidney Alexander's 1952 article expounding the absorption approach to the effects of devaluations.

The third generosity concerns a small point: Whitman does imply that global monetarism made it obvious to all that exchange rates represent the relative prices of national moneys. I cannot imagine that anybody ever thought they represented anything else.

The fourth instance of generosity is in crediting the monetarists with the conclusion that rules about intervention in the exchange market are not enough to prevent inconsistent policies. Of course, rules about intervention can only prevent inconsistent intervention policies. That other policies, such as monetary policy, affect the foreign-exchange market has long been recognized.

On policy matters, the paper is also unduly generous in dealing with the global-monetarist view that changes in the exchange rate affect the price level but not the current-account balance. This view has no revolutionary implications for policy. It is confined to the long-run effects of changes in exchange rates that are made from an initial position of equilibrium. It has little application to balance-of-payments problems as they arise in the real world. It appears revolutionary only because the proponents of the globalmonetarist view do not make clear that this is only a long-term effect, and applies only to a devaluation made from a position of equilibrium. If one accepts their assumptions that all relative prices are determined by real demand and supply functions and that these functions are not affected by monetary changes, the conclusions that they reach seem quite justified. Then, a change in exchange rates will not alter the current-account balance. But those assumptions, if applied to periods no longer than a few years, also imply that the exchange rate could never have gotten out of equilibrium in the first place. Why, then, would a devaluation occur? 
Ultimately, Whitman raised this question but she waited very long to do so, and until she did so she took the analysis too seriously as a contribution to exchange-rate policy. The conclusion that the global monetarists reach about the effects on the current-account balance of changing an exchange rate would be valid as a forecast of what would happen, perhaps, if a country devalued from equilibrium in order to perform a scientific experiment. Although the model that leads to those conclusions is helpful in focusing attention on some aspects of changes in exchange rates that were previously neglected, the things that it excludes and must exclude in order to reach its extreme conclusions make it positively misleading as a guide to policy. Therefore, the application of that solution to a serious policy issue deserves more severe criticism than Whitman gave it.

When it is recognized that devaluations occur from positions of disequilibrium, one interesting question that arises is whether and under what conditions the predevaluation disequilibrium will tend to be reestablished. That is a question that really is relevant to policy, but it is ignored by the global monetarists and in the paper. I suggest that, when the cause of the disequilibrium is in some sense monetary, a devaluation can cure it, provided that monetary policy does not counteract the effects of the devaluation. But if the cause is real and there is no money illusion, devaluation will not cure it. For example, if the balance of payments is in deficit because the groups in the economy insist on maintaining or restoring real absorption (consumption plus investment) that exceeds the total national product plus the maximum possible capital import, the deficit in the total balance of payments cannot be cured by a devaluation because the excess absorption will persist or recur.

In general, I think the useful and stimulating recent contributions to balance-of-payments theory and policy have come from the monetary approach to the balance of payments, not from global monetarism.

\section{General Discussion}

In general, the participants felt that Marina Whitman had illuminated some important controversies in international economic analysis; hence, most of them offered views or evidence on some of the unresolved issues, rather than specific criticisms of the paper.

Hendrik Houthakker focused on purchasing-power parity, commenting that, although in some quarters it had been regarded as an absurdity just a while ago, it was now being advanced, in global monetarism, as an identity. 
In his judgment, purchasing-power parity was neither absurdity nor identity but something in between; just where it lay on that spectrum was an important topic for research. Houthakker saw it as a useful indicator of exchange rates for the long run and, when the discrepancy is very large, for the medium term as well. But he doubted that, when the discrepancy was, say, 10 percent, it told very much about the likely course of exchange rates, given the imperfections of markets. He shared Lawrence Krause's puzzlement about prices of meat and other traded goods that apparently don't equalize. In response to a suggestion from Whitman, he expressed doubts that these cases could be fully explained by the different distribution systems among countries that may apply differing markups to the wholesale prices of traded goods.

William Fellner remarked that, in popular discussion of the issues examined in the paper, a key question is whether, under a flexible-rate regime, a country has control of its domestic price level. He felt that two propositions that are often confused needed to be distinguished clearly. On the one hand, if a country is in its preferred position with respect to demand management and price-level movements, it can insulate itself from price-level increases that originate abroad. In a regime of flexible rates, such disturbances will be neutralized. On the other hand, when a country acts to alter its demand position-say, increases its level of employment through expansionary stabilization policies-the income expansion tends to raise its imports, and thus to lower the value of its currency and raise the domestic prices of foreign goods. Hence, the price-level consequences of demandmanagement policies are influenced by the flexibility of exchange rates in a way that cannot readily be neutralized. Robert Solomon suggested, and Fellner agreed, that, in Fellner's example, the need for expansionary policies implied some prior recession or weakness in demand, which presumably must have exerted downward influence on domestic prices through flexible exchange rates.

In Richard Cooper's opinion, the literature reviewed by Whitman had exerted one important constructive influence. It had helped economists to recognize that in the short run exchange rates may be determined substantially, even primarily, by stock equilibrium in asset markets rather than by the current account. While this idea is not new, Cooper noted, the new emphasis on it had greatly influenced professional discussions of exchangerate issues. Until recently, the relationship between the exchange rate and the current account got nearly all the attention. As Cooper saw the interac- 
tions, in a regime of flexible rates, traded goods and services really establish a long-run supply price for a currency, while the floating exchange rate clears the asset market in the short run, thereby triggering quantity adjustments in the current account that restore long-term asset equilibrium. In such a system, the exchange rate will overshoot its long-run equilibrium in response to many (though not all) disturbances. That overshooting can impose important social costs in the presence of market imperfections or discontinuities, such as dependence on internal financing, bankruptcy, or asymmetrical responses of domestic prices to appreciation and depreciation. These, in turn, make the volatility of exchange rates a proper concern of public policy.

Furthermore, Cooper explained, because asset markets are regarded as important, so are speculation and the formation of expectations. He judged that private speculative movements during recent years had smoothed the Canadian dollar quite well, but the Deutsche mark inadequately, vis-à-vis the U.S. dollar. Those divergent experiences raise questions about the potential contribution of official intervention in smoothing exchange rates. Thus, the key issues are: what is the optimum degree of flexibility for exchange rates, and what role should government intervention play in pursuing that optimum?

Branson elaborated on Cooper's discussion of the asset determination of exchange rates, pointing to policy proposals for splitting currency markets so that exchange rates applying to current-account transactions could be controlled while those for capital movements would be free. Such policy measures might insulate the real sector, in part, from fluctuations originating in asset markets. Cooper noted that such proposals assumed that arbitrage between the two markets could be prevented; both he and Krause inferred from the scattered available evidence that the ability to split those markets was sharply limited. Rudiger Dornbusch pointed out that the kind of overshooting described by Cooper would occur even if speculation was fully consistent with rational expectations. Further, if such an event was experienced, he cautioned, central-bank intervention to correct it might conflict with the objectives of domestic stabilization policy.

Max Corden inspected the proposition that the exchange rate has no real effects, concluding that its validity depends on assumptions that the Phillips curve is vertical, and that no rigidities exist in the money prices for factors or goods. Hence, that view is likely to appeal to the same people who find those assumptions congenial in their analysis of domestic phe- 
nomena. In short, Corden felt, anyone who believes that fiscal policy does not affect employment and output is likely to accept the hard-line globalmonetarist view that variations in exchange rates also have no real effects.

In Dornbusch's view, no one could seriously doubt the presence of real effects of the exchange rate in the short run; the important questions concern their duration and the channels through which they disappear. In addition, Dornbusch disagreed with Krause's comment that the topdown approach to the balance of payments is appropriate for the analysis of the consequences of real disturbances. He stressed that even real disturbances influence interest rates in general and equity prices in relation to capital-goods prices (Tobin's $q$ ) in particular; these effects require a generalequilibrium analysis that encompasses both the financial and the real sectors.

Arthur Okun probed into the sterilization issue. As he saw it, the conditions under which a central bank could not control its domestic money supply in the face of foreign inflows (or outflows) were ones in which foreign near-moneys are perfect substitutes for near-moneys denominated in the domestic currency. But, in that situation, he insisted, foreign money would be a virtually perfect substitute for domestic money, most obviously as a cash balance for financial transactions. Income velocity, measured in terms of the domestic money stock, would then be highly unstable. Thus, the assumptions about asset demands that preclude control over the domestic money stock also mean that such control doesn't matter. The assumptions of the global monetarist are inconsistent with the traditional monetarist tenet that the demand function for domestic money is stable.

Branson's formulation of the international monetary issues in an IS-LM framework evoked favorable comment, but also a few criticisms. Fellner stressed that, if a country could not, in fact, control its money stock, as the global monetarists insisted, the position of the LM curve could not be managed by the central bank, and hence the analogy to the Blinder-Solow formulation of fiscal policy broke down. Dornbusch questioned the validity of the aggregation of foreign and domestic demands for goods implicit in the construction of an IS curve.

Marina Whitman responded to a few of the issues raised during both the formal and the general discussion. She was amused that she was most frequently criticized for excessive kindness and generosity. She did not rebut that criticism-perhaps out of kindness and generosity. She agreed with Walter Salant on the relevance of the divergence between prices and costs, 
noting that the global monetarists ignored it by focusing on a long-run equilibrium in which prices must equal costs. Responding to Corden's comment, she agreed that anyone who saw real income as exogenously determined in general, would see no real effects from exchange rates. But, she insisted, one could believe that real income was affected by domestic aggregate demand and yet not by the exchange rate, insofar as the domestic price level might respond rapidly to changes in the exchange rate but more slowly to shifts in aggregate demand. 